\title{
Impact of natural and anthropogenic aerosols on stratocumulus and precipitation in the Southeast Pacific: a regional modelling study using WRF-Chem
}

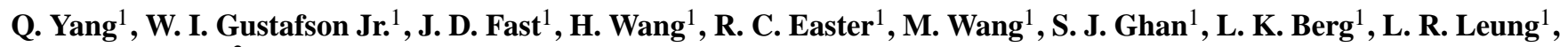 \\ and H. Morrison ${ }^{2}$ \\ ${ }^{1}$ Pacific Northwest National Laboratory, Richland, WA, USA \\ ${ }^{2}$ National Center for Atmospheric Research, Boulder, CO, USA \\ Correspondence to: Q. Yang (qing.yang@pnnl.gov)
}

Received: 21 May 2012 - Published in Atmos. Chem. Phys. Discuss.: 8 June 2012

Revised: 6 September 2012 - Accepted: 7 September 2012 - Published: 28 September 2012

\begin{abstract}
Cloud-system resolving simulations with the chemistry version of the Weather Research and Forecasting (WRF-Chem) model are used to quantify the relative impacts of regional anthropogenic and oceanic emissions on changes in aerosol properties, cloud macro- and microphysics, and cloud radiative forcing over the Southeast Pacific (SEP) during the VAMOS Ocean-Cloud-Atmosphere-Land Study Regional Experiment (VOCALS-REx) (15 October-16 November 2008). Two distinct regions are identified. The near-coast polluted region is characterized by low surface precipitation rates, the strong suppression of non-sea-salt particle activation due to sea-salt particles, a predominant albedo effect in aerosol indirect effects, and limited impact of aerosols associated with anthropogenic emissions on clouds. Opposite sensitivities to natural marine and anthropogenic aerosol perturbations are seen in cloud properties (e.g., cloud optical depth and cloud-top and cloud-base heights), precipitation, and the top-of-atmosphere and surface shortwave fluxes over this region. The relatively clean remote region is characterized by large contributions of aerosols from non-regional sources (lateral boundaries) and much stronger drizzle at the surface. Under a scenario of five-fold increase in regional anthropogenic emissions, this relatively clean region shows large cloud responses, for example, a $13 \%$ increase in cloudtop height and a $9 \%$ increase in albedo in response to a moderate increase ( $25 \%$ of the reference case) in cloud condensation nuclei $(\mathrm{CCN})$ concentration. The reduction of precipitation due to this increase in anthropogenic aerosols more than doubles the aerosol lifetime in the clean marine boundary
\end{abstract}

layer. Therefore, the aerosol impacts on precipitation are amplified by the positive feedback of precipitation on aerosol, which ultimately alters the cloud micro- and macro-physical properties, leading to strong aerosol-cloud-precipitation interactions. The high sensitivity is also related to an increase in cloud-top entrainment rate (by $16 \%$ at night) due to the increased anthropogenic aerosols. The simulated aerosolcloud-precipitation interactions due to the increased anthropogenic aerosols have a stronger diurnal cycle over the clean region compared to the near-coast region with stronger interactions at night. During the day, solar heating results in more frequent decoupling of the cloud and sub-cloud layers, thinner clouds, reduced precipitation, and reduced sensitivity to the increase in anthropogenic emissions. This study shows the importance of natural aerosols in accurately quantifying anthropogenic forcing within a regional modeling framework. The results of this study also imply that the energy balance perturbations from increased anthropogenic emissions are larger in the more susceptible clean environment than in already polluted environment and are larger than possible from the first indirect effect alone.

\section{Introduction}

Anthropogenic aerosols change the energy balance of the Earth's climate system through the direct effect of absorbing and scattering radiation as well as indirect effects of changing cloud albedo and precipitation. The first indirect effect 
was first postulated by Twomey (1977) to describe the brightening of clouds due to smaller and more numerous cloud droplets in response to an increase in cloud condensation nuclei $(\mathrm{CCN})$ at constant liquid water content. The conventional second indirect effect describes how increases in CCN suppress warm rain formation, leading to longer cloud lifetime, larger liquid water path (LWP), and greater cloudiness (Albrecht, 1989). However, large eddy simulation (LES) studies of aerosol impact on precipitating marine stratocumulus have revealed complex microphysical and dynamical feedbacks that are more complicated than traditionally depicted as the second indirect effect (e.g., Wang and Feingold, 2009a; Stevens and Feingold, 2009, and references therein). The large uncertainties related to aerosol direct and first indirect effects limit our understanding of the anthropogenic forcing on the climate system (Solomon et al., 2007). The processes and feedbacks through which aerosols affect clouds and precipitation are less well understood and are more difficult to quantify in climate models. The Intergovernmental Panel on Climat Change (IPCC) fourth assessment report (AR4) provided a first indirect effect forcing estimate of -0.22 to $-1.85 \mathrm{~W} \mathrm{~m}^{-2}$, and its uncertainty was the largest among various contributors to anthropogenic forcing (Solomon et al., 2007).

Over the ocean, aerosols from natural sources (e.g. sea salt and sulfate from DMS oxidation) play an important role in determining cloud properties and the perturbations to clouds and precipitation by anthropogenic aerosols. Seasalt particles are emitted from the ocean through sea spray, bubble bursting, and spume associated with wave-breaking (Gong et al., 1997), and their emission strength is windspeed dependent. Sea-salt particles are hygroscopic and have larger surface areas than anthropogenic aerosols, such as sulfate. Therefore, the condensation of gaseous sulphuric acid and water preferentially occur on them, thus inhibiting new particle formation, lowering the maximum supersaturation in clouds and suppressing the activation of anthropogenic aerosols in clouds (Ghan et al., 1998). Sea-salt particles could also serve as giant (e.g., $>2 \mu \mathrm{m}$ ) and ultra-giant (e.g., $>10 \mu \mathrm{m}) \mathrm{CCN}$, and have been found to promote drizzle production (Feingold et al., 1999), decrease total droplet number (Rosenfeld et al., 2002), and reduce LWP in polluted clouds (Lu and Seinfeld, 2005). In addition, sea-salt particles in different size ranges can impact clouds differently (Kogan et al., 2012).

The oxidation of dimethyl sulfide (DMS) is a source of secondary aerosols, non-sea-salt sulfate aerosol, over the ocean. Charlson et al. (1987) postulated that an increase in DMS emissions could exert a cooling effect on the climate system (Charlson et al., 1987). However, using simulations from several climate models, Woodhouse et al. (2010) found a relatively weak climate response to DMS due to the low sensitivity of $\mathrm{CCN}$ concentrations to the change in DMS emissions.
Marine stratocumulus clouds are ideal for studying the relative roles of natural and anthropogenic aerosols in changing cloud properties and radiative forcings. This is because their overall cooling effect is important to the earth's energy budget and also because these boundary layer clouds are often close to emission sources. With a large and persistent stratocumulus cloud deck (Klein and Hartmann, 1993) and a complex mixture of aerosols from anthropogenic and marine sources (Chand et al., 2010; Kleinman et al., 2012; Shank et al., 2012), the Southeast Pacific (SEP) is an ideal location for studying effects of aerosols on shallow warm clouds. Observations from the VAMOS Ocean-Cloud-AtmosphereLand Study Regional Experiment (VOCALS-REx; Wood et al., 2011b) show distinctly different cloud and precipitation features over the remote and near-coast regions over the SEP associated with low and high concentrations of CCN (e.g., Bretherton et al., 2010b; Painemal and Zuidema, 2010; Wood et al., 2011a; Zheng et al., 2011; Zuidema et al., 2012), which resemble the pristine precipitating and the polluted non-precipitating cloud regimes predicted by previous studies (e.g., Baker and Charlson, 1990).

Process models, such as LES and Mixed Layer Models (MLM), have often been used to study marine stratocumulus clouds. MLM are used to study the steady state solutions of a group of thermodynamic equations with fixed external forcings such as mean subsidence, sea surface temperature (SST), and lower-tropospheric divergence (e.g., Bretherton and Wyant, 1997; Pincus and Baker, 1994; Stevens, 2006; Wood, 2007). The main advantage of LES is its ability to resolve turbulent eddies. LES are often idealized and conducted with small domains (on the order of $10^{2} \mathrm{~km}^{2}$ or smaller) to study the equilibrium state or diurnal cycle of clouds under horizontally uniform forcing conditions (e.g., Berner et al., 2011; Chen et al., 2011; Lu and Seinfeld, 2005; Sandu et al., 2008; Wang and McFarquhar, 2008a, b). With a relatively large domain (on the order of $10^{4} \mathrm{~km}^{2}$ ), the LES can simulate the response of mesoscale cloud structures to aerosol perturbations, but only in very ideal meteorological scenarios with prescribed large-scale forcings (Kazil et al., 2011; Mechem et al., 2012; Wang and Feingold, 2009a, b).

The climate modeling community is actively engaged in improving the representation of aerosol and aerosol-cloudradiation interactions in regional and global models. Increased computational resources have permitted the application of regional models with prognostic aerosols and coupled aerosol-cloud-radiation processes, such as the chemistry version of the Weather Research and Forecast model (WRFChem, Fast et al., 2006; Grell et al., 2005), to the study of aerosol-cloud interactions (ACI) under realistic meteorological conditions. The use of realistic meteorological conditions allows for simulating complex interactions between clouds and meteorological factors and their feedbacks to larger-scale dynamics. In addition to LES and MLM, regional models with interactive aerosols and coupled aerosol-cloud-radiation 
processes can be important tools for advancing our understanding of aerosol effects on regional climate.

WRF-Chem has been used in a wide range of applications including air quality, aerosol-cloud-precipitation studies, and regional climate (e.g., Fast et al., 2012; Gao et al., 2011; Qian et al., 2009; Zhang et al., 2010). Q. Yang et al. (2011) and Saide et al. (2012) evaluated WRF-Chem simulations of aerosols, clouds, precipitation, and their interactions over the SEP during VOCALS-REx using extensive measurements from the field campaign and satellite retrievals. Comparisons with observations showed that the model performed well in simulating aerosol (e.g., AOD, accumulation mode aerosol number, submicron aerosol mass) and clouds (e.g., cloud top and cloud base height, cloud fraction, cloud water path). The well-simulated cloud properties fed back to the dynamics and improved the simulated boundary-layer characteristics as well as surface and top-of-atmosphere (TOA) energy fluxes. Q. Yang et al. (2011) and Saide et al. (2012) also demonstrated that WRF-Chem was able to simulate the synopticscale variations of aerosol and cloud properties over the SEP in response to the pollution outflow from South America.

In this study, WRF-Chem simulations are used to quantify and compare the impacts of anthropogenic and natural oceanic emissions on aerosol properties, cloud macro- and microphysics, and cloud radiative forcings over the SEP during VOCALS-REx. Aerosol-cloud-precipitation interactions in polluted and clean regions are investigated. We are among the first to use a regional model with prognostic aerosols and coupled aerosol-cloud-radiation to study the relative contributions of oceanic and anthropogenic aerosols to changes in cloud properties and radiative forcings over the SEP under realistic meteorological conditions at cloud-system resolving scale. The analysis is based on month-long simulations. Thus, the results represent responses to varying synoptic conditions over a longer time period than those in typical LES and MLM modeling studies, and hence can provide insights into the aerosol-cloud-precipitation interactions and their impact on climate.

The remainder of this paper is organized as follows. The WRF-Chem model and the simulations are described in Sect. 2. The response of aerosol number concentrations and optical properties to regional anthropogenic and oceanic emissions is discussed in Sect. 3.1. The response of cloud microphysical and optical properties is presented in Sect. 3.2, followed by cloud macro-properties, precipitation, and radiative forcing in Sects. 3.3, 3.4, and 3.5, respectively. Finally, Sect. 4 summarizes the main conclusions and implications of this study.

\section{Model description and experimental design}

\subsection{Model description}

The WRF-Chem model includes online interactions between aerosols, radiation, clouds and precipitation for the direct, semi-direct, and first and second indirect effects of aerosols as described in Fast et al. (2006), Chapman et al. (2009), Gustafson et al. (2007), and Q. Yang et al. (2011). The simulations presented in this study were performed using the code that was released to the public in v3.3. The detailed model description and configuration can be found in Q. Yang et al. (2011), and here the model configuration is only briefly summarized.

Gas-phase chemistry is simulated with a version of the CBMZ mechanism that includes DMS chemistry (Zaveri and Peters, 1999). The MOdel for Simulating Aerosol Interactions and Chemistry (MOSAIC, Zaveri et al., 2008) provides an integrated treatment of aerosol chemical and microphysical processes. MOSAIC uses an 8-bin sectional approach to represent aerosol size distributions for both unactivated (i.e., interstitial) and activated (i.e. cloud-borne) aerosols, with both mass and number simulated for each bin. MOSAIC calculates condensation and evaporation of gas species (such as $\mathrm{H}_{2} \mathrm{SO}_{4}, \mathrm{MSA}, \mathrm{HNO}_{3}, \mathrm{HCl}$, and $\mathrm{NH}_{3}$; Zaveri et al., 2008) using an accurate thermodynamic module that predicts particle deliquescence, water content and solid-liquid phase equilibrium in multicomponent aerosols (Zaveri et al., 2008). Aerosol coagulation, aerosol nucleation, and aqueous chemistry (in cloud droplets) are also treated. The aerosol activation scheme (Abdul-Razzak and Ghan, 2000) is based on the maximum supersaturation, which is diagnosed based on both the resolved vertical velocity and the parameterized turbulent motions. Particles are assumed internally mixed within each model size bin, and Köhler theory is used to relate the aerosol size distribution and composition to the number activated as a function of the maximum supersaturation (Abdul-Razzak and Ghan, 2000). For calculating number concentrations of $\mathrm{CCN}\left(N_{\mathrm{CCN}}\right)$ at a supersaturation, a narrow lognormal sizedistribution is assumed for the particles within a size bin. The aerosol composition of the bin gives a volume-weighted hygroscopicity, from which the dry-diameter for a specified critical supersaturation is calculated. The particles in the bin with dry-diameter exceeding this critical diameter contribute to $N_{\mathrm{CCN}}$.

The cloud microphysics is represented with the Morrison double-moment scheme (Morrison et al., 2009) that was recently coupled with interactive aerosols (Q. Yang et al., 2011). In the Morrison double-moment microphysics, the cloud droplet number concentration and cloud water mixing ratio are used to determine a gamma distributed cloud droplet size spectrum, which affects various microphysical process including autoconversion. Changes of number concentrations and mass mixing ratios of cloud water are predicted in the scheme based on sources (primarily water vapor 
condensation) and sinks (e.g., autoconversion and accretion). Other hydrometeor species, including raindrops, are assumed to follow an exponential distribution (Morrison et al., 2009). The autoconversion scheme is based on Khairoutdinov and Kogan (2000) using an explicit autoconversion rate:

$\frac{\partial q}{\partial t}=1350 Q_{\mathrm{c}}^{2.47} N_{\mathrm{c}}^{-1.79}$

where $Q_{\mathrm{c}}$ and $N_{\mathrm{c}}$ are cloud water mixing ratio and droplet number concentration, respectively. Unlike some other autoconversion parameterizations (e.g., Manton and Cotton, 1977), this formula does not include any threshold effective radius, but does implicitly depend on mean droplet radius given its dependence on both $Q_{\mathrm{c}}$ and $N_{\mathrm{c}}$ (i.e., mean droplet radius is proportional to $\left.\left(Q_{\mathrm{c}} / N_{\mathrm{c}}\right)^{1 / 3}\right)$.

Aerosols impact clouds, and clouds also impact aerosols in the model. In-cloud wet scavenging is the main sink of submicron particles while cloud chemistry provides a major source of sulfate. Wet scavenging of aerosols refers to the removal of both cloud-borne/activated and interstitial/unactivated aerosols by precipitation, although the cloudborne aerosol wet scavenging dominates. The cloud-borne aerosol wet-scavenging rate is assumed equal to the normalized rate at which cloud water is converted to precipitation $\left(\mathrm{s}^{-1}\right)$, and includes contributions from cloud water autoconversion and collection by rain in the Morrison microphysics. In WRF-Chem, evaporation of cloud droplets in dry air resuspends cloud-borne aerosol back to the interstitial state. The complete evaporation of a raindrop will also resuspend the rain-borne particulate matter as a single (and relatively large) particle, but this process was not treated in our WRF simulations. This resuspension by evaporating raindrops would have little impact on the simulated CCN number concentrations (at $s=0.1 \%$ ), as a raindrop is typically composed of hundreds to thousands of cloud droplets (and activated $\mathrm{CCN}$ ), but the evaporation releases a single large CCN. The aerosol impacts on clouds and shortwave radiation for the first indirect effect are implemented by linking the predicted cloud droplet number from the Morrison microphysics scheme with the Goddard shortwave radiative scheme. The effect of aerosols on precipitation is handled directly by the microphysics scheme for warm-rain processes, where the number of activated particles affects cloud droplet number, autoconversion rate, and precipitation.

The YSU scheme (Hong et al., 2006) is used to represent turbulent vertical mixing associated with the boundary layer. In the YSU scheme, the non-local mixing due to large eddy transport is considered for heat and momentum components, and an explicit treatment of entrainment is included in the heat and momentum flux profiles and the growth of the planetary boundary layer (PBL) height (Noh et al., 2003; Shin and Hong, 2011). This parameterized PBL entrainment in the YSU scheme is not equivalent to cloud-top entrainment (S. Hong, personal communication, 2012) since the YSU scheme assumes the PBL top as the minimum flux level as

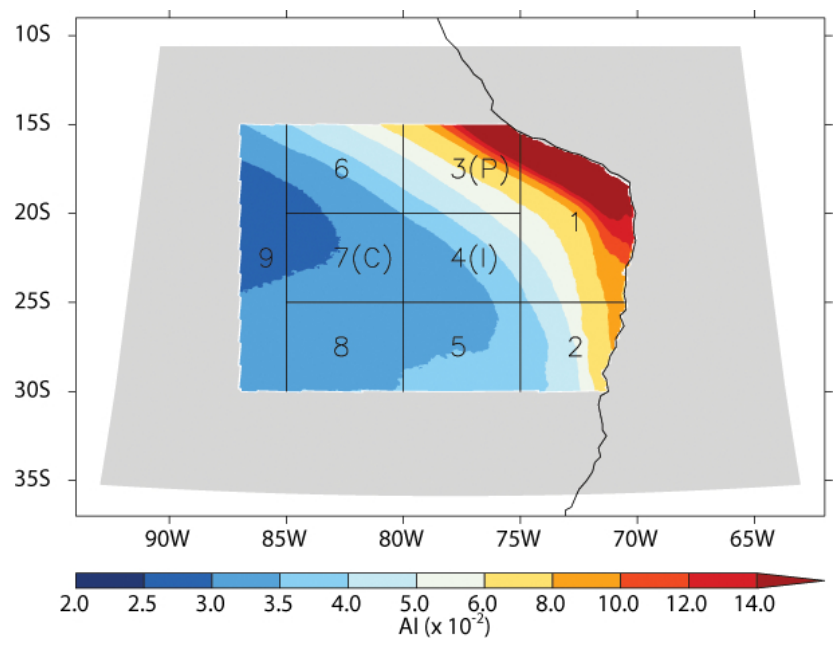

Fig. 1. Monthly average aerosol indexes (AI) during the VOCALSREx period. The modeling domain is divided into 9 regions (numbered by $1-9$ ) with the regions $3-8$ being $5^{\circ} \times 5^{\circ}$ in sizes. Regions 3,4 , and 7 are also referred as polluted (P), intermediate (I), and clean $(\mathrm{C})$ regions in the main text. The grey area shows the model domain. Areas too close to the lateral boundaries are not included in this study.

explicitly formulated, and the PBL height from YSU was found to be near the cloud base or mid-level of the stratocumulus clouds. The cloud-top entrainment discussed later likely results from parameterized local mixing, the resolvedscale motion, and complex feedback between microphysics and the PBL scheme.

\subsection{Experimental design}

Excluding five days of model spin-up, simulations are conducted from 00:00 UTC, 15 October to 00:00 UTC, 16 November 2008. The model domain is roughly from $63^{\circ} \mathrm{W}$ to $93^{\circ} \mathrm{W}$ in longitude and from $11^{\circ} \mathrm{S}$ to $36^{\circ} \mathrm{S}$ in latitude and includes parts of the northern Chilean and southern Peruvian coasts and the nearby Southeast Pacific (see Fig. 1). The horizontal grid spacing is 9-km and the vertical grid spacing increases from $\sim 30 \mathrm{~m}$ in depth near the surface to $\sim 50 \mathrm{~m}$ at $1 \mathrm{~km}$ height. Initial and boundary conditions for meteorology and time dependent sea surface temperatures were obtained from the Global Forecast System (GFS) with a 0.5-degree grid spacing, while the initial and boundary conditions for trace gases and aerosols were provided by the global Model for OZone and Related chemical Tracers (MOZART).

The simulation described and evaluated by Q. Yang et al. (2011; called the AERO experiment therein) is used as the reference simulation (REF hereafter) in this study. The emission inventory compiled for the VOCALS model assessment provides anthropogenic emissions including both point and area sources. Ultrafine, fine, and coarse mode $(<10 \mu \mathrm{m})$ sea-salt emissions are parameterized based on Clarke et al. (2006), Gong et al. (1997), and Monahan et 
Table 1. Description of four primary model simulations.

\begin{tabular}{lll}
\hline Simulations & Emissions included & Description of simulations \\
\hline REF & $\begin{array}{l}\text { AnthroEmis } \\
+ \text { OceanEmis }\end{array}$ & $\begin{array}{l}\text { Standard/reference } \\
\text { simulation }\end{array}$ \\
\hline 0OCE & AnthroEmis & $\begin{array}{l}\text { Sea salt and DMS emissions } \\
\text { turned off }\end{array}$ \\
\hline 0ANT & OceanEmis & $\begin{array}{l}\text { Anthropogenic emissions } \\
\text { turned off }\end{array}$ \\
\hline 5ANT & ScaledEmis & $\begin{array}{l}\text { Anthropogenic emissions } \\
\text { scaled by a factor of 5 }\end{array}$ \\
\hline
\end{tabular}

al. (1986), respectively. DMS emissions are based on a simplified Nightingale et al. (2000) scheme. A detailed description of the emissions and the coupling of aerosol-cloudradiation processes can be found in Q. Yang et al. (2011).

One challenge in studying cloud-aerosol interactions is the difficulty in separating the aerosol-induced changes from meteorology-induced changes in cloud properties because aerosol and meteorological characteristics tend to be correlated (Loeb and Schuster, 2008; Stevens and Feingold, 2009). Therefore, for the purpose of quantifying separately the effects of different emission sources within the model domain, three sensitivity runs (Table 1) are conducted with one simulation having continental emissions turned off (0ANT), one with primary (sea salt) and secondary precursor (DMS) oceanic emissions turned off (OOCE), and one with continental emissions increased by a factor of 5 (5ANT). We acknowledge that a factor of 5 is arbitrary; however, the purpose is to produce a significant increase in anthropogenic aerosols over the remote ocean $(\sim 25 \%$ increase in CCN at $0.1 \%$ supersaturation). The results are, therefore, a somewhat extreme scenario, and the magnitude of the response would likely be smaller for scenarios having smaller changes to anthropogenic emissions, although we expect that in each region the sign of the response will likely be the same as that of the 5ANT. The continental emissions are primarily anthropogenic but also contain volcanic emissions. The continental emissions are also referred to as regional anthropogenic emissions in consideration of the dominance of anthropogenic sources and the negligible impacts of volcanic emissions to our results.

The effects of regional anthropogenic and oceanic emissions are estimated by contrasting sensitivity simulations with the reference simulation, REF. The effect of anthropogenic emissions from continental sources within the domain (AnthroEmis) is calculated as the difference in simulated quantities between REF and OANT. Similarly, the regional oceanic emission effect (OceanEmis) is calculated as the difference between REF and OOCE. The effect of the increased anthropogenic emissions (ScaledEmis) is defined as the difference between 5ANT and REF. Contrasting sensitivity simulations with REF facilitates the estimation of emission-induced changes, and isolates the impacts due to the differences in meteorology. The purpose of the sensitivity simulation with oceanic emissions turned off is to help illustrate the importance of locally emitted oceanic particles within a regional modeling framework. It might be taken for granted that with the presence of background oceanic particles, the representation of local sea-salt/DMS emissions in a regional model is not important for the purpose of estimating the effect of anthropogenic aerosol over the polluted region. In addition, there are large uncertainties in sea salt emissions treated in contemporary models, and due to the strong dependence of sea-salt emissions on wind speed, the emissions have large temporal and spatial variability. For those reasons, a test of this "external perturbation" in oceanic emissions is meaningful. The remote clean marine region is an interesting region with about twice as high wind speed as the near-coast region and several times higher sea-salt emission rates; however, the precipitation scavenging is also much stronger. This sensitivity study also helps determine sources of CCN over the remote ocean.

To assist with the diagnosis, additional 10-day sensitivity simulations (excluding spin-up periods) are also conducted. The first supplementary sensitivity simulation turns off boundary conditions of gas and aerosol species, the second has no DMS emission but retains sea-salt emission, and the third turns off the new particle nucleation process.

The total aerosol and cloud radiative forcing at the surface is calculated as the difference between surface shortwave fluxes under all-sky conditions and under clear and clean conditions. The current version of WRF-Chem does not compute the aerosol and cloud forcing on-line, so an offline utility (Barnard et al., 2010), that replicates the radiation calculation in WRF-Chem using hourly WRF-Chem output data, was used to estimate the total aerosol and cloud radiative forcing in the REF simulation.

\section{Aerosol, cloud, precipitation, and energy flux responses to regional emissions}

The aerosol index (AI) is dominated by contributions from anthropogenic aerosols (compared to sea-salt and dust; Matsui et al., 2006), and is used to illustrate the strong anthropogenic influence over the SEP. The AI is calculated as the product of AOD at $550 \mu \mathrm{m}$ and the Ångström coefficient between $400 \mu \mathrm{m}$ and $700 \mu \mathrm{m}$. Q. Yang et al. (2011) showed that the simulated AOD at $550 \mu \mathrm{m}$ agrees well with the MODIS retrievals in mean spatial distribution pattern and the domain average $(0.10 \pm 0.06$ and $0.11 \pm 0.06$ for the MODIS and REF, respectively) during VOCALS-REx. The horizontal distribution of the monthly-average AI over the ocean is shown in Fig. 1 for the REF simulation. The large gradient in AI near the coast reflects the strong influence from continental emission sources. This is consistent with the observed longitudinal gradient of aerosol concentrations during 

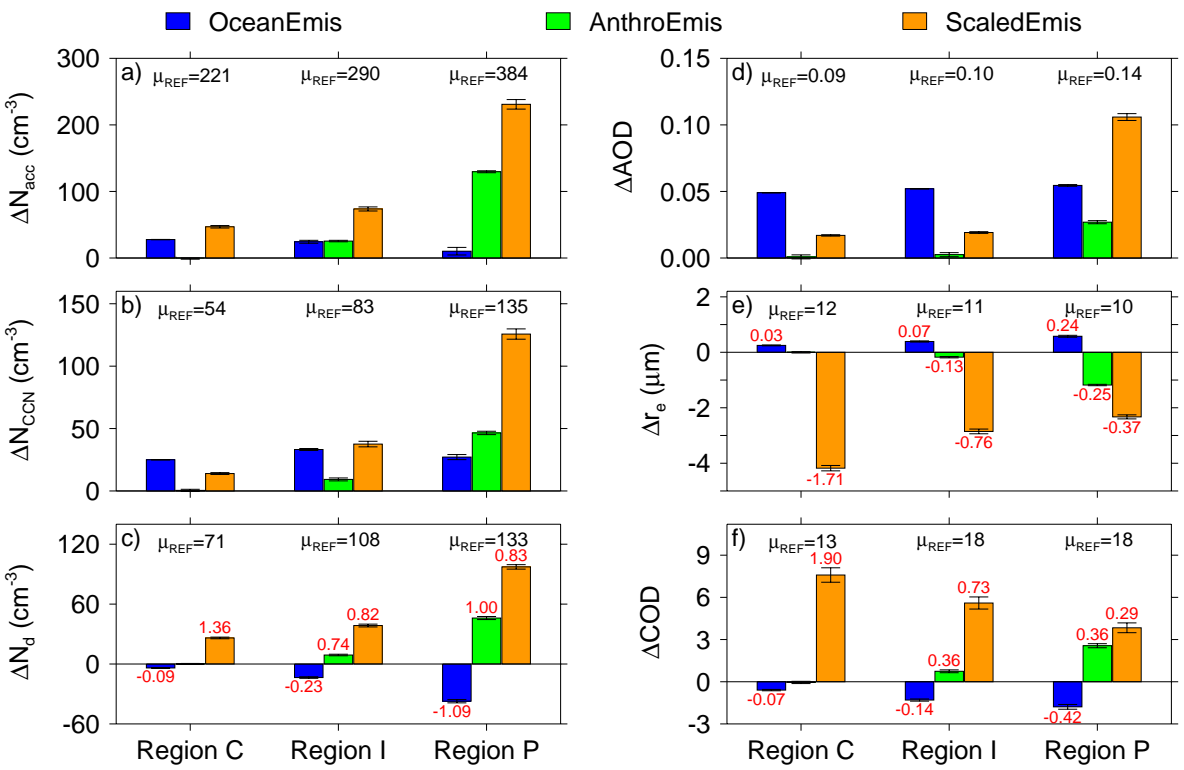

Fig. 2. Responses of aerosol and cloud properties to regional oceanic (OceanEmis, blue), anthropogenic (AnthroEmis, green), and enhanced anthropogenic (ScaledEmis, orange) emissions. The response, " $\Delta$ ", denotes differences in simulated quantities between two simulations with and without the specific regional emissions: REF-0OCE, REF-0ANT, and 5ANT-REF are used for assessing the response due to OceanEmis, AnthroEmis, and ScaledEmis, respectively. Panels (a-f) are for mean changes in accumulation mode aerosol $\left(N_{\mathrm{a}}\right.$, panel (a) at $\left.975 \mathrm{hPa}\right), \mathrm{CCN}$ $\left(N_{\mathrm{CCN}}\right.$ at $0.1 \%$ supersaturation at $975 \mathrm{hP}$, panel b), cloud-top cloud droplet number $\left(N_{\mathrm{d}}\right.$, panel c), aerosol optical depth (AOD, panel d), cloud top effective radius ( $r_{\mathrm{e}}$, panel e), and cloud optical depth (COD, panel f), respectively. The mean aerosol or cloud properties in the reference simulation are shown at the top of each panel for each region (regions $\mathrm{P}, \mathrm{I}$, and $\mathrm{C}$ ) as $\mu_{\mathrm{REF}}$. The aerosol-cloud sensitivity factors, $\frac{\Delta \ln (Y)}{\Delta \ln \left(N_{\text {ccn }}\right)}$, are shown in red above or below each color bar, where $Y$ is the cloud property (e.g., $N_{\mathrm{d}}, r_{\mathrm{e}}$, and COD). More details regarding the aerosol-cloud sensitivity factor are provided in the main text. The error bars show the $95 \%$ confidence intervals of the mean changes estimated based on the temporal variation of hourly spatially averaged responses in each region.

VOCALS-REx (e.g., Allen et al., 2011; Bretherton et al., 2010b; Hawkins et al., 2010). For the purpose of contrasting emission effects at different regions over the ocean, the marine area within the domain (excluding areas close to lateral boundaries) is divided into 9 regions (numbered by $1-$ 9 , Fig. 1) with the regions $3-8$ being $5^{\circ} \times 5^{\circ}$ in size. Three specific regions 3,4 , and 7 with high, intermediate, and low AI values, which represent polluted (region P), intermediate (region I), and clean (region C) marine environments, respectively, have been selected for detailed analysis. These three regions are also differentiated by their relative distances from the coastline. The selection intentionally avoids regions close to the southern inflow boundary. The selected regions also correspond to low (region P), intermediate (region I) and high (region $\mathrm{C}$ ) values of the aerosol-cloud interaction indices, which will be discussed later in this section.

\subsection{Aerosol}

Figure $2 \mathrm{a}-\mathrm{b}$ shows the contributions of regional oceanic (OceanEmis), anthropogenic (AnthroEmis), and enhanced anthropogenic emissions (ScaledEmis) to number concentrations of accumulation mode aerosols $\left(N_{\mathrm{acc}}\right)$ and $\mathrm{CCN}$ (at supersaturation $s=0.1 \%$ ) at $\sim 975 \mathrm{hPa}$. The selection of $N_{\mathrm{CCN}}$ at $s=0.1 \%$ follows previous VOCALS studies (Bretherton et al., 2010b; Q. Yang et al., 2011). In this study, we use accumulation mode aerosols to refer to particles with dry diameters of $0.078-1.25 \mu \mathrm{m}$ with most of those particles in the $0.078-0.31 \mu \mathrm{m}$ dry diameter range. The average contribution of the regional oceanic emissions to $N_{\text {acc }}$ increases from $2 \%\left(\Delta N_{\mathrm{acc}}=10 \mathrm{~cm}^{-3}\right)$ over region $\mathrm{P}$ to $10 \%\left(\Delta N_{\text {acc }}=27 \mathrm{~cm}^{-3}\right)$ over region C. OceanEmis contributions to $N_{\mathrm{CCN}}$ are larger: $20 \%\left(\Delta N_{\mathrm{CCN}}=27 \mathrm{~cm}^{-3}\right), 39 \%$ $\left(\Delta N_{\mathrm{CCN}}=33 \mathrm{~cm}^{-3}\right)$, and $46 \%\left(\Delta N_{\mathrm{CCN}}=25 \mathrm{~cm}^{-3}\right)$ for regions $\mathrm{P}, \mathrm{I}$, and $\mathrm{C}$, respectively.

Regional anthropogenic emissions contribute $33 \%$ $\left(\Delta N_{\text {acc }}=129 \mathrm{~cm}^{-3}\right.$ and $\left.\Delta N_{\mathrm{CCN}}=46 \mathrm{~cm}^{-3}\right)$ to $N_{\text {acc }}$ and $N_{\mathrm{CCN}}$ over region $\mathrm{P}$, and their contribution decreases to $\sim 10 \%\left(\Delta N_{\mathrm{acc}}=25 \mathrm{~cm}^{-3}\right.$ and $\left.\Delta N_{\mathrm{CCN}}=9 \mathrm{~cm}^{-3}\right)$ over region I and $\sim 0 \%$ over the more remote region $\mathrm{C}$. Consistent with the climatology over the SEP, a persistent surface-high pressure system was centered near $95^{\circ} \mathrm{W}, 32^{\circ} \mathrm{S}$ during VOCALS-REx, and the marine boundary layer (MBL) air circulates around the center of the high pressure system. The streamlines in Fig. 13a of Toniazzo et al. (2011) showed predominant marine influence over region $\mathrm{C}$ by horizontal transport. 
The high $\frac{\Delta N_{\mathrm{CCN}}}{\Delta N_{\mathrm{acc}}}$ ratios for OceanEmis $(0.92-2.7$ over the three regions) compared to AnthroEmis ( 0.36 over both regions $\mathrm{P}$ and I) are due to a combination of the larger hygroscopicity and the larger sizes of sea-salt particles. The simulated aerosol size distributions (figures not shown) also suggest that the addition of sea-salt particles inhibit the growth of small non-sea-salt particles (dry diameter $<0.078 \mu \mathrm{m}$ ) to accumulation mode size. This simulated inhibition is only present over the polluted region $\mathrm{P}$, and it contributes to the low $\Delta N_{\text {acc }}$ from OceanEmis over this region (Fig. 2a). A supplementary simulation with DMS emissions turned off indicates that DMS emissions lead to a $6 \%$ increase $\left(23 \mathrm{~cm}^{-3}\right)$ in $N_{\text {acc }}$ relative to the REF over region P, but its contribution to $N_{\text {acc }}$ is reduced away from the coast with a negligible contribution over region C. Associated with the over-prediction of the DMS emission scheme under high-wind conditions (Blomquist et al., 2006), the simulated DMS ocean-to-air transfer velocity was overestimated by about $70 \%$ compared to observations (Q. Yang et al., 2011); thus the actual DMS effect might be even smaller.

When subtracting $N_{\mathrm{acc}}$ and $N_{\mathrm{CCN}}$ contributed by both AnthroEmis and OceanEmis from their mean total concentrations in the REF, the residuals account for aerosols originating from lateral boundaries, natural aerosols originating from continental sources (excluding volcanic aerosols), and the likely non-linear responses of $N_{\text {acc }}$ and $N_{\mathrm{CCN}}$ to changes in emissions. A supplementary sensitivity simulation (BND, Fig. 3) with no aerosols and gas chemical species from the lateral boundaries shows $\sim 85 \%$ (region I) and $\sim 95 \%$ (region C) reductions of both $N_{\mathrm{acc}}$ and $N_{\mathrm{CCN}}$ concentrations from those of the REF, suggesting a dominant aerosol influence from outside the model domain for regions I and C. Over region $\mathrm{P}$, contrasting the BND and REF simulations indicates that approximately $25 \%$ and $35 \%$ of $N_{\text {acc }}$ and $N_{\mathrm{CCN}}$ originate from lateral boundaries, respectively. The southern boundary of the model domain is the main low-level inflow boundary during VOCALS-REx. Southeasterly winds prevail within the MBL with reduced wind speed towards the coast during the VOCALS-REx (Rahn and Garreaud, 2010), and mean surface winds are approximately southerly at $20^{\circ} \mathrm{S}$ near the coast, and southeasterly $\left(125^{\circ}\right)$ at $20^{\circ} \mathrm{S}, 85^{\circ} \mathrm{W}$ (Toniazzo et al., 2010).

With the five-fold increase in anthropogenic emissions, the mean $N_{\mathrm{CCN}}$ increased by $90 \%\left(120 \mathrm{~cm}^{-3}\right), 44 \%\left(37 \mathrm{~cm}^{-3}\right)$, and $25 \%\left(13 \mathrm{~cm}^{-3}\right)$ over regions $\mathrm{P}, \mathrm{I}$, and $\mathrm{C}$, respectively. Over the remote region, the $25 \%$ increase in $N_{\mathrm{CCN}}$ due to the enhanced anthropogenic emissions (ScaledEmis) compared to the negligible impact of AnthroEmis in REF can be explained by the reduced precipitation (weaker aerosol sink and longer aerosol lifetime) and the increased cloud-top entrainment (stronger source of MBL aerosol) in 5ANT, which are discussed later.

The relationships between emission strength and $N_{\text {acc }}$ are nonlinear for both oceanic and anthropogenic emissions. For example, the response of $N_{\text {acc }}$ to ScaledEmis in each re-
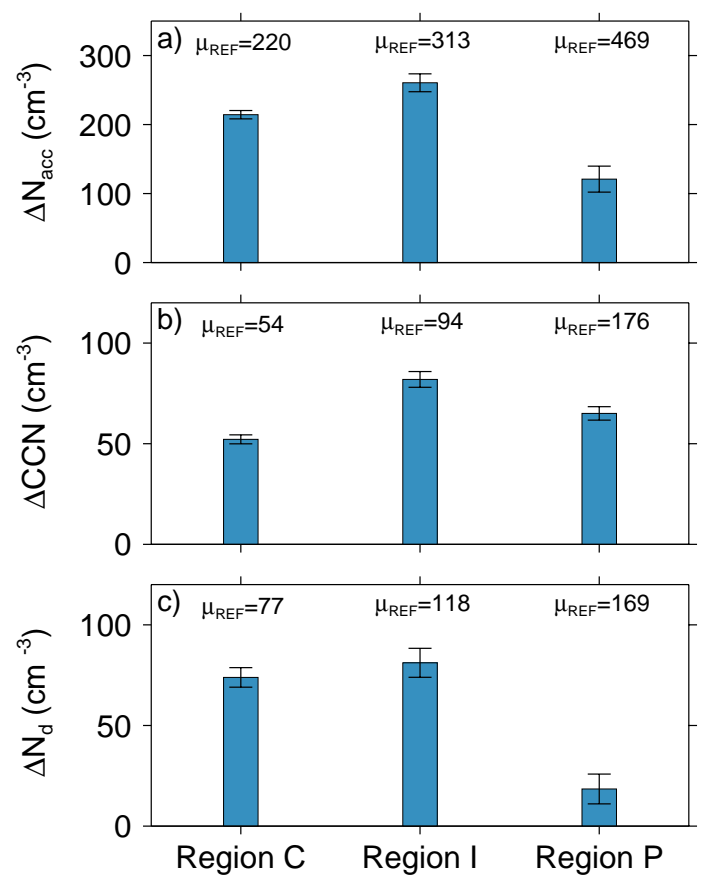

Fig. 3. Mean responses in accumulation mode aerosol $\left(N_{\mathrm{a}}\right.$, panel a) at $975 \mathrm{hPa}, \mathrm{CCN}\left(N_{\mathrm{CCN}}\right.$ at $0.1 \%$ supersaturation at $975 \mathrm{hP}$, panel b), and cloud-top cloud droplet number $\left(N_{\mathrm{d}}\right.$, panel c) due to aerosols and gas chemical species from lateral boundaries for regions $\mathrm{P}, \mathrm{I}$, and $\mathrm{C}$. The mean response, " $\Delta$ ", denotes differences in simulated quantities between two simulations with and without aerosols and gas species from the lateral boundaries for a 10-day (15-24 October 2008) simulation period (excluding spin-ups). The mean aerosol or cloud properties in the reference simulation for the corresponding period are shown at the top of each panel for each region (regions $\mathrm{P}, \mathrm{I}$, and $\mathrm{C}$ ) as $\mu_{\mathrm{REF}}$.

gion is not four-times [(5ANT-1ANT)/(1ANT-0ANT)] the response to AnthroEmis. This is associated with the highly nonlinear nature of aerosol processes including nucleation, coagulation, condensational growth of existing particles from gas-phase chemicals (such as the uptake of gas-phase $\mathrm{H}_{2} \mathrm{SO}_{4}$ by sea-salt particles), and wet removal.

The AOD response to different emissions is shown in Fig. 2d. Regional oceanic emissions have large contributions $(40-50 \% ; 0.05-0.06)$ to AOD over all three regions, mostly due to sea-salt particles. Mean 10-m wind speeds and seasalt emissions over regions $\mathrm{C}$ and $\mathrm{I}$ are about twice as large as region $\mathrm{P}$; however, the wet removal is also stronger over regions $\mathrm{C}$ and $\mathrm{I}$. The near-coast region $\mathrm{P}$ is downwind of the near-shore low-level jet region, thus, the high sea-salt concentrations advected by southerly flow is also likely to contribute to the high AOD response to sea-salt emissions over region $\mathrm{P}$. Over region $\mathrm{P}$, AnthroEmis contributes only about half as much to AOD compared to that of OceanEmis, and its contributions are negligible over regions I and C. 

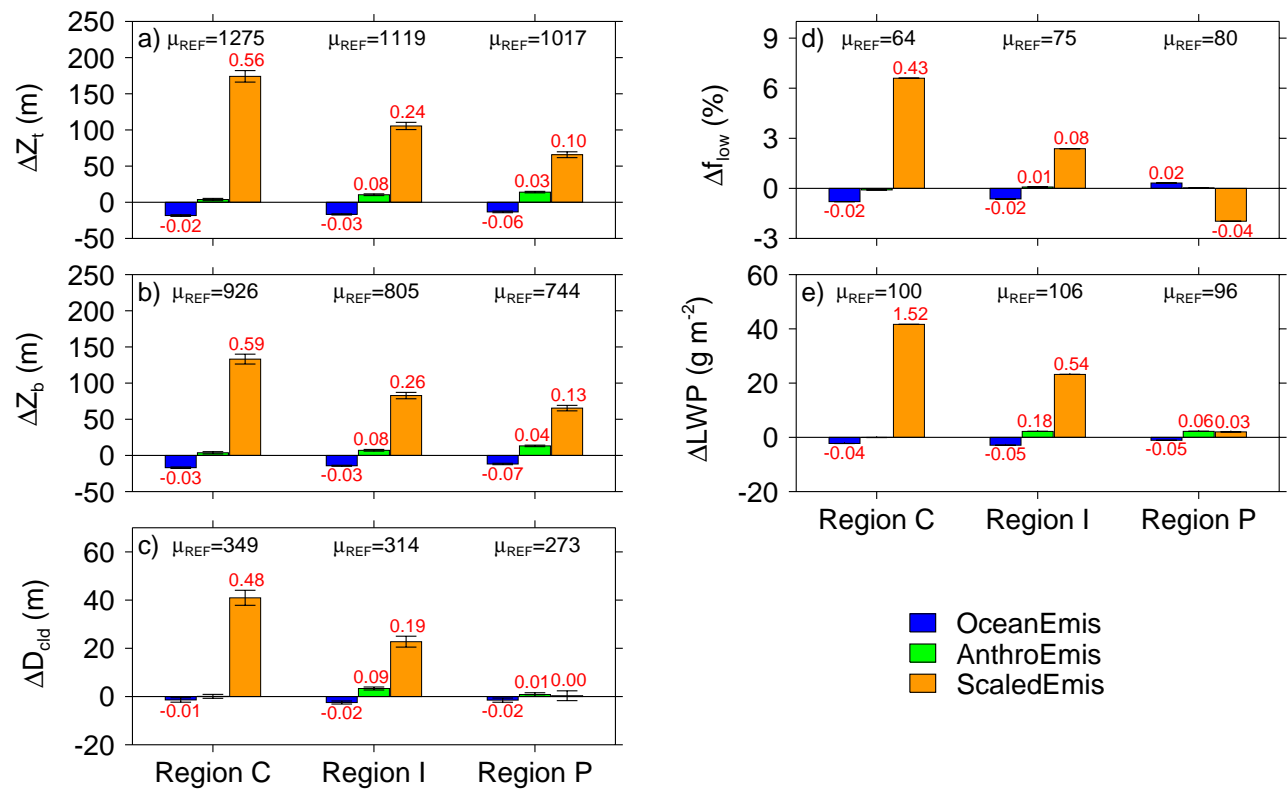

Region C Region I Region P

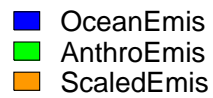

Fig. 4. Same as in Fig. 2 but for responses of mean cloud top height $\left(Z_{\mathrm{t}}\right.$, panel a), cloud base height $\left(Z_{\mathrm{b}}\right.$, panel b), cloud depth $\left(D_{\mathrm{cld}}\right.$, panel c), low cloud fraction ( $f_{\text {low }}$, panel d), and liquid water path (LWP, panel e) to regional oceanic (OceanEmis, blue), anthropogenic (AnthroEmis, green), and scaled anthropogenic (ScaledEmis, orange) emissions.

\subsection{Cloud microphysical and optical properties}

The changes in cloud properties due to emissions are discussed below in terms of absolute and relative changes as well as aerosol-cloud sensitivity factors in order to contrast ACI strength in the three regions. Following studies in the current literature (e.g., Feingold et al., 2001; Quaas et al., 2009; Wang et al., 2011), we define aerosol-cloud sensitivity factor as the relative change in a mean cloud property (e.g., LWP and $r_{\mathrm{e}}$ ) between a sensitivity simulation and the REF with respect to the change in some measure of the aerosol in a column (i.e., a proxy, such as AI). For the purpose of evaluating the sensitivity of boundary layer clouds to either oceanic or anthropogenic emissions, $\mathrm{CCN}$ at $\sim 975 \mathrm{hPa}$ is chosen as the proxy. Therefore, when evaluating the cloud property responses to emissions, the aerosol-cloud sensitivity factor is defined as

$\operatorname{CLDSF}_{\mathrm{CCN}}(Y)=\frac{\Delta \ln (Y)}{\Delta \ln (\mathrm{CCN})}$,

where $Y$ is a cloud property, and " $\Delta$ " is the difference between the regional temporal averages of two simulations. Note that partial derivatives are approximated with finite differences from different model simulations and are used to quantify the sensitivity of cloud properties to changes in aerosol from either anthropogenic sources or natural sources over near-coast and remote regions. Similar use of such partial derivatives (approximated by finite differences) can be found in the literature such as Chen et al. (2011). This definition using differences is different from that in some other papers (e.g., Feingold et al., 2003; Quaas et al., 2009), where the aerosol-cloud interactions are quantified by performing a linear regression of cloud parameters against aerosol parameters. Note that Penner et al. (2011) found a significant difference between these two methods. The aerosol-cloud sensitivity factor is in principle similar to the precipitation susceptibility that is discussed later in Sect. 3.4. The values of these sensitivity factors for each region are shown in red in Figs. 2c, e, and $f$ and 4.

The cloud-top droplet number concentration $\left(N_{\mathrm{d}}\right)$ increases with increasing anthropogenic emissions (Fig. 2c). Regional anthropogenic emissions (AnthroEmis) contribute $34 \%\left(46 \mathrm{~cm}^{-3}\right)$ and $8 \%\left(9 \mathrm{~cm}^{-3}\right)$ to $N_{\mathrm{d}}$ over regions $\mathrm{P}$ and I, respectively. The $\operatorname{CLDSF}_{\mathrm{CCN}}\left(N_{\mathrm{d}}\right)$ values are $0.83,0.82$, and 1.36 over regions $\mathrm{P}, \mathrm{I}$, and $\mathrm{C}$ with ScaledEmis, and the higher sensitivity factor over region $\mathrm{C}$ indicates more efficient aerosol activation over the clean marine environment. Increased anthropogenic emissions (ScaledEmis) lead to a $36 \%\left(26 \mathrm{~cm}^{-3}\right)$ increase in the mean $N_{\mathrm{d}}$ concentration over region C. As shown in Fig. 3c, contrasting the BND and REF simulations indicates that approximately $11 \%$ of $N_{\mathrm{d}}$ over region $\mathrm{P}$ originates from lateral boundaries. Over regions I and $\mathrm{C}$, the significant decrease of $N_{\mathrm{d}}$ in the BND from that of the REF $\left(\Delta N_{\mathrm{d}}\right.$ of $\sim 70 \%$ and $95 \%$ over regions I and C, respectively) indicate the dominant source of $N_{\mathrm{d}}$ from lateral boundaries.

The addition of oceanic emissions, in contrast, decreases $N_{\mathrm{d}}$ by $27 \%\left(37 \mathrm{~cm}^{-3}\right), 12 \%\left(13 \mathrm{~cm}^{-3}\right)$, and $5 \%\left(3 \mathrm{~cm}^{-3}\right)$ over regions $\mathrm{P}, \mathrm{I}$, and $\mathrm{C}$, respectively. The addition of large sea-salt particles lowers the maximum supersaturation, which suppresses activation of the more numerous 
submicron particles, resulting in fewer cloud droplets (Ghan et al., 1998). This water vapor competition effect is expected with the parameterized aerosol activation scheme. As was described in Sect. 3.1 with respect to $\Delta N_{\text {acc }}$, sea-salt particles inhibit some fine non-sea-salt particles from growing to viable $\mathrm{CCN}$ sizes, and this could also contribute to the reduction in $N_{\mathrm{d}}$. The sea-salt suppression of droplet activation from non-sea-salt particles is most pronounced over the polluted region as shown by the more negative $\operatorname{CLDSF}_{\mathrm{CCN}}\left(N_{\mathrm{d}}\right)$ of -1.1 over region $P$ compared to that of region $C(-0.1)$, consistent with Ghan et al. (1998). The decrease in $N_{\mathrm{d}}$ due to the sea-salt suppression effect dominates the increase in $N_{\mathrm{d}}$ due to secondary oceanic emissions (DMS oxidation; $\Delta N_{\mathrm{d}}=\sim 8 \%$ of the REF; $11 \mathrm{~cm}^{-3}$ ).

The cloud-top droplet effective radius, $r_{\mathrm{e}}$, is calculated directly within the microphysics scheme based on the predicted droplet size distributions. As shown in Fig. 2e, anthropogenic aerosols (AnthroEmis and ScaledEmis) reduce $r_{\mathrm{e}}$ over region P, reflecting the albedo effect. Over this region, anthropogenic aerosols induce a $12 \%(1.2 \mu \mathrm{m})$ decrease in $r_{\mathrm{e}}$, and the $r_{\mathrm{e}}$ sensitivity to oceanic aerosols is half of this magnitude but of opposite sign. In region $\mathrm{C}$, the addition of $\sim 13 \mathrm{~cm}^{-3}$ CCN (25\% increase) leads to a $35 \%(-4.2 \mu \mathrm{m})$ reduction of mean $r_{\mathrm{e}}$. By definition, the first indirect effect assumes constant liquid water content, and Feingold et al. (2003) proposed a theoretical upper limit of 0.33 for indirect effect (similar to $-\operatorname{CLDSF}_{\mathrm{CCN}}\left(r_{\mathrm{e}}\right)$ ) for a homogenous cloud with constant liquid water content. The simulated aerosolcloud sensitivity factor over the region $\mathrm{P}$ are within this limit. However, the large changes in $r_{\mathrm{e}}$ due to the relatively small increase in anthropogenic aerosols over region $\mathrm{C}$ indicate aerosol impacts on precipitation, LWP, and related microphysical and dynamical feedbacks, which are discussed in more detail in Sect. 3.4. Associated with the increased sensitivity of clouds to anthropogenic aerosols over region $\mathrm{C}$, the east-west gradient of the response to AnthroEmis is reversed with ScaledEmis with the largest response over region C.

The changes in cloud optical depth (COD) are consistent with the large changes in $r_{\mathrm{e}}$. Anthropogenic emissions contribute a $4-14 \%$ increase in COD, while oceanic emissions induce $7-9 \%$ reduction. Related to the stronger sea-salt effect in suppressing small particle activation over the polluted region, region $\mathrm{P}$ has the largest reduction $(-1.8 ; 10 \%)$ in COD due to OceanEmis, followed by regions I $(-1.5 ; 8 \%)$ and $\mathrm{C}(-0.5 ; 4 \%)$. In the clean region $\mathrm{C}, \mathrm{COD}$ is more sensitive to ScaledEmis $\left(\mathrm{CLDSF}_{\mathrm{CCN}}=1.9\right)$ compared to region $\mathrm{P}$ $(0.3-0.4)$. A relatively small increase in $N_{\mathrm{d}}\left(26 \mathrm{~cm}^{-3} ; 36 \%\right)$ in region $\mathrm{C}$ due to ScaledEmis leads to a $54 \%$ increase in COD, which has a major contribution from changes in LWP (discussed in the next section).

\subsection{Cloud macro-properties}

This section discusses the changes in cloud heights, cloud thickness, cloud fraction, and liquid water path with emis- sions. These simulated cloud properties in REF have been evaluated against observations in Q. Yang et al. (2011), and an overall good agreement in the features of the distribution and mean values were demonstrated. For example, the simulated mean cloud-top height (approximation of MBL heights) and mean cloud thickness in REF agree with observations within $10 \%$, and the simulated cloud fraction has a mean low bias of 2-3\% during VOCALS-REx (Q. Yang et al., 2011).

As shown in Fig. 4a, regional oceanic emissions reduce the mean cloud-top heights by $13-18 \mathrm{~m}$ over the three regions, while regional anthropogenic emissions elevate the mean cloud-top heights by 14 and $10 \mathrm{~m}$ over regions $\mathrm{P}$ and I, respectively. These changes are small but statistically significant, and the $98 \%$ confidence intervals for the mean changes are shown as error bars in Fig. 4. With the increased anthropogenic emissions, stronger responses are seen in the cloudtop $\left(Z_{\mathrm{t}}\right)$ and cloud-base heights (e.g., $\operatorname{CLDSF}_{\mathrm{CCN}}\left(Z_{\mathrm{t}}\right)=$ 0.56 ; and $\Delta Z_{\mathrm{t}}=174 \mathrm{~m}$, which is $13 \%$ of REF) over region $\mathrm{C}$ compared to those over region $\mathrm{P}$ (e.g., $\operatorname{CLDSF}_{\mathrm{CCN}}\left(Z_{\mathrm{t}}\right)=$ $0.10 ; \Delta Z_{\mathrm{t}}=65 \mathrm{~m}$, which is $6 \%$ of REF).

The sensitivity of cloud-top heights to anthropogenic and oceanic aerosols are also linked to cloud-top entrainment. Entrainment is an important process related to water and static energy distributions within the MBL, and transport of aerosols from the free troposphere (e.g., Raes, 1995; M. Yang et al., 2011). Cloud-top entrainment rates in the simulations are estimated using a budget analysis (Eq. 4 of Yang et al., 2009) of a passive tracer, as described in Q. Yang et al. (2011). The nighttime entrainment rates over regions $P$, $\mathrm{I}$ and $\mathrm{C}$ increase by $3 \%, 6 \%$ and $16 \%$ in 5ANT compared to the REF. The enhanced entrainment increases the amount of aerosols entrained from the free troposphere, although increases in MBL height dilute the MBL aerosols to some extent. Based on LES simulations of marine stratocumulus clouds, Ackerman et al. (2004) found that cloud-top entrainment increases with increasing $N_{\mathrm{d}}$. For non-drizzling stratocumulus clouds, a later study by Bretherton et al. (2007) linked the $N_{\mathrm{d}}$-induced entrainment change with droplet sedimentation. Studying a nocturnal non-drizzling stratocumulus layer using LES with bulk microphysics, cloud droplet sedimentation was found to decrease entrainment rates because removal of liquid water from the entrainment zone reduces both evaporative cooling and longwave radiative cooling, with evaporative cooling found to be more important than radiative cooling in changing entrainment rates (Bretherton et al., 2007). In our simulations, cloud droplet sedimentation in the double-moment Morrison microphysics scheme depends explicitly on droplet size distribution. An increase in $N_{\mathrm{d}}$ leads to smaller droplet sizes resulting in reduced droplet sedimentation velocity. Therefore, it is expected that an increase in anthropogenic aerosols leads to smaller cloud droplets, which reduce cloud droplet sedimentation, and results in an increase in entrainment rate (Bretherton et al., 2007; Hill et al., 2009) and higher cloud tops. Additional 4-day sensitivity simulations with droplet size fixed 
for calculation of sedimentation in REF and 5ANT (assuming an effective radius of $12 \mu \mathrm{m}$ ), thereby excluding interactions between $N_{\mathrm{d}}$, sedimentation, and entrainment, support the interpretation that sedimentation account for most of the changes in cloud-top entrainment.

The increase in cloud-top entrainment rates is more pronounced with ScaledEmis over drizzling region $\mathrm{C}$, and larger sensitivity of cloud-top heights to $N_{\mathrm{d}}$ changes are also found over this region. Oceanic emissions contribute very little to the mean $N_{\mathrm{d}}$ over regions $\mathrm{C}$ compared to P (see Fig. 2c, $-5 \% /-3 \mathrm{~cm}^{-3}$ vs. $-27 \% /-37 \mathrm{~cm}^{-3}$ ), and yet they result in a similar mean response to cloud-top heights. This could be linked to the role of drizzle in promoting reduction in entrainment over heavily drizzling region (Stevens et al., 1998). Over the clean region, reduced precipitation $(\sim 65 \%$ reduction in cloud-base and near-surface rain rate) due to enhanced anthropogenic emissions (ScaledEmis) leads to a reduction of both below-cloud evaporative cooling and in-cloud latent heat release, resulting in stronger turbulence and thus an increase in the kinetic energy available for the cloud-top entrainment (Stevens et al., 1998; Lu and Seinfeld, 2005; Wood, 2007). Due to evaporation of drizzle below cloud base, the strongly drizzling clouds tend to form a cooler and moister subcloud layer (Stevens et al., 1998), and this is consistent with the simulated warmer $(\Delta T=0.2 \mathrm{~K})$ and less humid $\left(\Delta q_{\mathrm{v}}=-0.2 \mathrm{~g} \mathrm{~kg}^{-1}\right.$, where $q_{\mathrm{v}}$ is the water vapor mixing ratio) MBL in 5ANT compared to the REF. More entrained dry air due to the increased entrainment is likely to contribute, at least in part to the less humid MBL simulated in 5ANT compared to the REF. Note that the simulated drier and warmer MBL in 5ANT is consistent with higher cloudbase heights (Fig. 4b). Due to the increased entrainment, the changes in virtual potential temperature $\left(\theta_{\mathrm{v}}\right)$, and humidity within the inversion layer are larger over region $\mathrm{C}$ compared to $\mathrm{P}$ ( 1.3 vs. $0.78 \mathrm{~g} \mathrm{~kg}^{-1}$ in $\Delta q_{\mathrm{v}}$ and -1.84 vs. $-1.27 \mathrm{~K}$ in $\left.\Delta \theta_{\mathrm{v}}\right)$.

The larger sensitivity of MBL heights to $N_{\mathrm{d}}$ changes over region $\mathrm{C}$ may also be driven by changes in the response of mesoscale dynamics between $\mathrm{C}$ and $\mathrm{P}$. It is also likely that the simulated drier and colder air overlying the MBL $\left(q_{\mathrm{v}}=0.91\right.$ and $2.3 \mathrm{~g} \mathrm{~kg}^{-1}$, and $\theta_{\mathrm{v}}=303.8$ and $308.2 \mathrm{~K}$ over regions $\mathrm{C}$ and $\mathrm{P}$, respectively, at $2 \mathrm{~km}$ height), when entrained into MBL, has a larger effect of enhancing droplet evaporation. Q. Yang et al. (2011) showed good agreement between the model-predicted and observed temperature and humidity profiles over the remote region $\left(78-88^{\circ} \mathrm{W}\right.$, along $\left.20^{\circ} \mathrm{S}\right)$ during VOCALS-REx. However, over the coastal region (east of $78^{\circ} \mathrm{W}$, along $20^{\circ} \mathrm{S}$ ), comparisons with dropsonde (Bretherton et al., 2010b) and radiosonde (de Szoeke et al., 2010) measurements found larger mean humidity biases of $\sim 1$.6$2.2 \mathrm{~g} \mathrm{~kg}^{-1}$ in the layer above MBL and below $2 \mathrm{~km}$. It is likely that over region $\mathrm{P}$, the simulated humidity in the layer right above the MBL is biased high, which is likely to reduce some of the predicted cloud height sensitivity to $N_{\mathrm{d}}$, although for the polluted conditions over region $\mathrm{P}$ the near cloud-top droplet sedimentation flux over region $\mathrm{P}$ is much smaller compared to region $\mathrm{C}$.

The cloud-base height response is similar to that of cloudtop height for both regional anthropogenic and oceanic emissions (Fig. $4 \mathrm{~b})$. Cloud depth ( $\left.D_{\text {cld }}\right)$ thus has minor changes due to regional oceanic emissions ( $\Delta D_{\text {cld }}=-1$ to $-2 \mathrm{~m}$ over the three regions) and anthropogenic emissions $\left(\Delta D_{\text {cld }}=3\right.$ and $\sim 0 \mathrm{~m}$ over region I and $\mathrm{P}$, respectively). The response of $D_{\text {cld }}$ to ScaledEmis is also negligible in the polluted region P. The changes in liquid water path (LWP) are consistent with the changes in cloud depth. The insensitivity of $D_{\text {cld }}$ and LWP to both anthropogenic and oceanic emissions over region $P$ indicates that the change in surface precipitation due to emissions is insufficient to modify $D_{\text {cld }}$ and LWP over this region. The limited impact of aerosols on $D_{\text {cld }}$ and LWP is also consistent with their limited impact on entrainment over region $\mathrm{P}$ as discussed above.

The cloud thickness and LWP are more sensitive to the increased anthropogenic emissions over the clean remote region than over the polluted region. Clouds were able to develop into a deeper state $\left(\Delta D_{\text {cld }}=11 \%\right.$ and $40 \mathrm{~m}$; $\Delta \mathrm{LWP}=41 \%$ and $41 \mathrm{~g} \mathrm{~m}^{-2}$ ) over the clean marine region with the addition of anthropogenic aerosols. This is consistent with results from Pincus and Baker (1994) who predicted that cloud thickness increases with $N_{\mathrm{d}}$, especially at low $N_{\mathrm{d}}$ conditions using a simple diurnally averaged steadystate mixed layer model. When anthropogenic aerosols are added over the clean region C, the increase in $D_{\text {cld }}$ and LWP due to lower precipitation (a weaker cloud water sink) dominates the reduction due to more entrainment of dry air. This results in a net increase in $D_{\text {cld }}$, LWP, and low cloud fraction ( $f_{\text {low }}$ is defined as cloud frequency below $700 \mathrm{hPa}$; Fig. 4e). $\mathrm{CLDSF}_{\mathrm{CCN}}(\mathrm{LWP})$ is as large as 1.5 , which is associated with large responses in cloud thickness $\left(\operatorname{CLDSF}_{\mathrm{CCN}}(D)=0.5\right)$, cloud frequency $\left(\operatorname{CLDSF}_{\mathrm{CCN}}\left(f_{\text {low }}\right)=0.4\right)$, and cloud water mixing ratios $\left(\operatorname{CLDSF}_{\mathrm{CCN}}\left(q_{\mathrm{c}}\right)=1.1\right)$.

Diurnal cycles of $Z_{\mathrm{t}}, Z_{\mathrm{b}}$, LWP, $D_{\text {cld }}$, and $f_{\text {low }}$ (see Fig. 5 for LWP) reveal that their responses to anthropogenic emissions over region $\mathrm{C}$ are most pronounced at night, and are very small between 14:00 and 20:00 local standard time (LST). The sensitivity of cloud macro-physical properties to $N_{\mathrm{d}}$ variations is reduced during the daytime because the absorption of solar radiation in the cloud layer offsets the cloud-top longwave radiative cooling and reduces convective mixing (Ackerman et al., 2003, 2004; Lu and Seinfeld, 2005). Solar heating was found to lead to more frequent decoupling of the cloud layer from the sub-cloud layer (e.g., Nicholls, 1984). Following Jones et al. (2011), decoupling is diagnosed from simulation results using humidity and potential temperature. Based on differences between the MBL layer below the inversion and the near-surface layer, the presence of moisture $\left(\Delta q_{\mathrm{v}}>0.5 \mathrm{~g} \mathrm{~kg}^{-1}\right)$ and/or temperature jumps $\left(\Delta \theta_{\mathrm{v}}>0.5 \mathrm{~K}\right)$ indicates a decoupling event. In cloudy conditions, daytime decoupling is more frequent over region $\mathrm{C}$ (with daytime maximum frequency of $\sim 42 \%$ between 
12:00-13:00 LST) compared to that of region $\mathrm{P}(\sim 30 \%)$ in REF. The increased daytime decoupling is also accompanied by less precipitation (diurnal minimum and maximum of 0.08 and $1.04 \mathrm{~mm} \mathrm{day}^{-1}$, respectively, in the REF). Clouds are also thinner during the day and diurnal cycle of LWP (Fig. 5) shows a diurnal minimum of $42 \mathrm{~g} \mathrm{~m}^{-2}$ at around 13:00 LST and a nighttime maximum of $139 \mathrm{~g} \mathrm{~m}^{-2}$ in the REF over region $\mathrm{C}$. The enhanced anthropogenic emissions have only a small impact on LWP during the day with the daytime minimum remain nearly unchanged. However, the LWP response to the enhanced anthropogenic aerosols during the night is much larger (with an increased diurnal maximum of $217 \mathrm{~g} \mathrm{~m}^{-2}$ compared to $139 \mathrm{~g} \mathrm{~m}^{-2}$ in the REF over region $\mathrm{C}$ ) and with larger response over region $\mathrm{C}$ compared to region P. Enhanced anthropogenic emissions (ScaledEmis) increase daytime maximum decoupling frequencies to $33 \%$ and $51 \%$ over regions P and C. Sandu et al. (2008) attributed the increased daytime decoupling frequencies due to anthropogenic aerosols in polluted clouds with reduced sensible heat flux, increased entrainment, and reduced evaporation resulting from precipitation suppression; this is consistent with our results. The stronger and more frequent decoupling during the daytime reduces the moisture supply to the cloud layer, and it also likely inhibits the transport of aerosols from the sub-cloud layer into the cloud layer contributing to the reduced sensitivity to emission changes compared to nighttime. This is supported by the simulated minimum $N_{\mathrm{d}}(\sim 35 \%$ lower than the diurnal mean) between 12:00 and 15:00 LST over region $\mathrm{C}$ with the enhanced anthropogenic emissions.

For a few scenarios of stratocumulus clouds over both the northeastern Atlantic and the coast of southern California, Ackerman et al. (2004) simulated $\operatorname{CLDSF}_{\mathrm{CCN}}$ (LWP) in the magnitude range of 0.06-0.35 using LES models. A LES study by Lu and Seinfeld (2005) showed CLDSF CCN $_{\text {(LWP) }}$ of 0.22 and 0.59 over polluted and clean conditions for the simulated nighttime stratocumulus cloud. Wang et al. (2011) obtained $\mathrm{CLDSF}_{\mathrm{CCN}}(\mathrm{LWP})$ values (for present day versus pre-industrial aerosols) of about 0.30 and 0.10 using a traditional global climate model (CAM5) and a multi-scale aerosol-climate model, respectively. The $\mathrm{CLDSF}_{\mathrm{CCN}}(\mathrm{LWP})$ values for regional anthropogenic emissions for regions $\mathrm{P}$ and $\mathrm{I}$ in this study are 0.06 and 0.18 , respectively, which are comparable to those in the literature. However, with the 5 -fold increase in anthropogenic emissions, the estimated $\mathrm{CLDSF}_{\mathrm{CCN}}(\mathrm{LWP})$ is much higher over region $\mathrm{C}$.

Over region $\mathrm{P}$, OceanEmis and AnthroEmis lead to a negligible increase in low-cloud fraction $\left(f_{\text {low }}\right)(<1 \%)$. ScaledEmis reduces $f_{\text {low }}\left(\Delta f_{\text {low }}=-1.9 \%\right.$, on average $)$ over region $\mathrm{P}$, which is opposite to the responses over regions I and C. Further investigation reveals that the opposite response occurs over locations (upper right corner of region P; also see Fig. 8 of Q. Yang et al., 2011) that are associated with synoptic induced subsidence and are typically cloud-free or have thin clouds ( $L W P<50 \mathrm{~g} \mathrm{~m}^{-2}$ ). The sedimentation effect could explain the simulated response over this near-coast

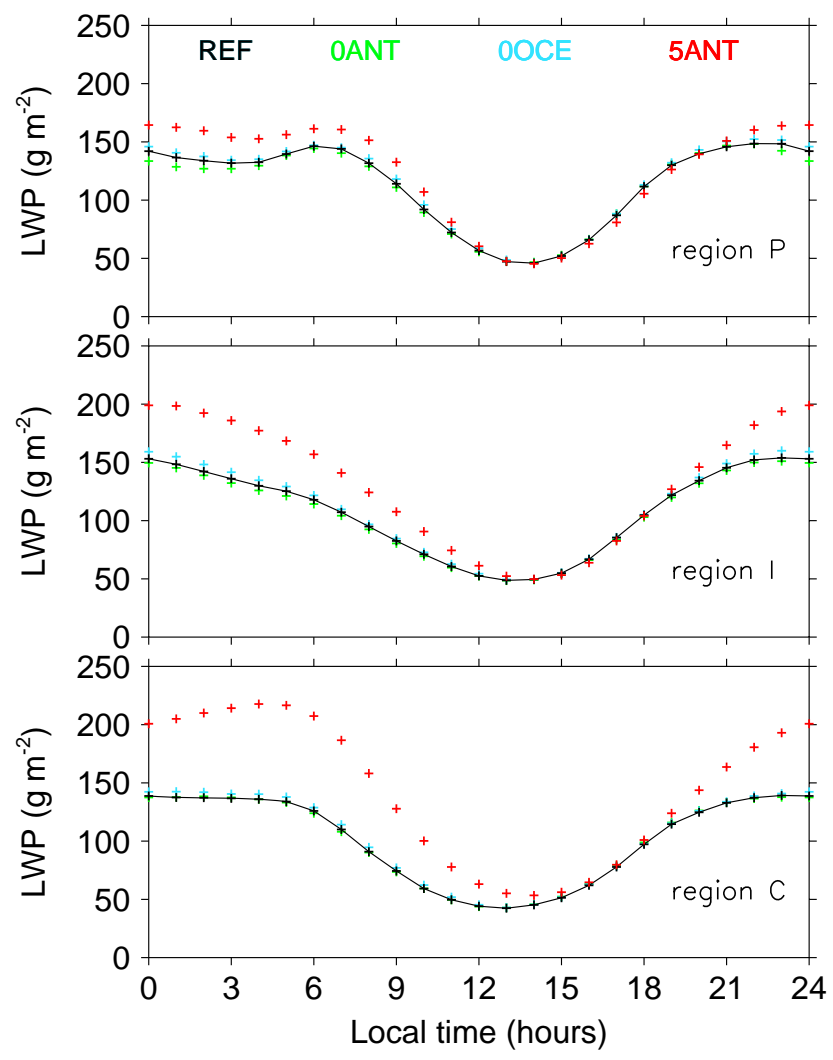

Fig. 5. Simulation period mean diurnal cycles of LWP in the reference simulation (REF, black solid line) and in the 3 sensitivity simulations with regional anthropogenic emissions turned off (OANT, green cross), with regional oceanic emissions turned off (0OCE, blue cross), and with scaled regional anthropogenic emissions (5ANT, red cross), respectively, for regions P (top), I (middle), and $\mathrm{C}$ (bottom).

area where increased $N_{\mathrm{d}}$ reduces sedimentation thus increasing entrainment rates, which contributes to the diminishing or further thinning of those thin clouds.

\subsection{Precipitation responses to aerosols}

Precipitation responses to aerosols over different regions are examined using probability of precipitation (POP) (e.g., L'Ecuyer et al., 2009), and precipitation susceptibility (e.g., Sorooshian et al., 2009). These tools have been used in recent studies to examine aerosol-cloud-precipitation interactions (e.g., POP in Freud and Rosenfeld, 2012; precipitation susceptibility in Terai et al., 2012) and to further constrain aerosol effects on cloud water amount in global climate models (Wang et al., 2012). Hourly outputs from each model grid column are used for the calculation of POP and precipitation susceptibility. POP is defined as the precipitation frequency of clouds at a given macrophysical condition, such as a fixed LWP. A precipitating event is defined as surface rain rates $(R)$ exceeding $0.12 \mathrm{~mm}$ day $^{-1}$ (i.e., 


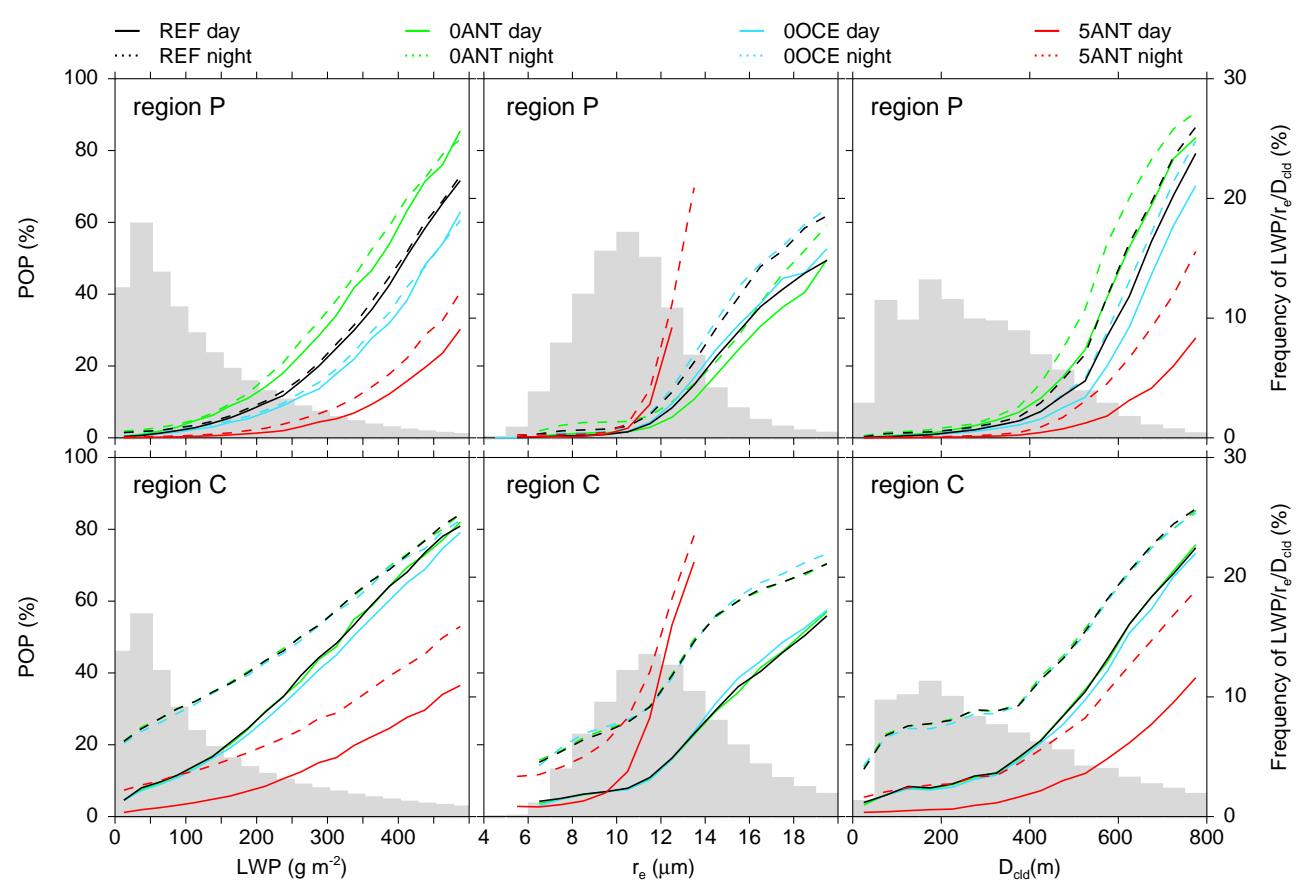

Fig. 6. Relationships between the probability of precipitation (POP) and liquid water path (LWP, left), cloud top effective radius $\left(r_{\mathrm{e}}\right.$, middle) and cloud thickness $(D$, right) during the day (solid lines) and the night (dashed lines) in the reference simulation (REF, black) and in the 3 sensitivity simulations with regional anthropogenic emissions turned off (0ANT, green), with regional oceanic emissions turned off (0OCE, blue), and with scaled regional anthropogenic emissions (5ANT, red), respectively, for two regions with low (region P) and high (region C) aerosol-cloud interactions. The histograms of LWP (left), $r_{\mathrm{e}}$ (middle), and $D$ (right) in the REF simulation are shown as the grey shaded areas. The figure is calculated based on hourly outputs on each model grid.

$0.005 \mathrm{~mm} \mathrm{~h}^{-1}$ ). Although POP values vary with the selection of the threshold surface rain rate, it does not alter the main conclusions drawn. A modified rain susceptibility is defined similar to aerosol-cloud sensitivity factors, but with an opposite sign: $S_{\mathrm{CCN}}=-\frac{\Delta \ln R}{\Delta \ln N_{\mathrm{CCN}}}=-\operatorname{CLDSF}_{\mathrm{CCN}}(R)$.

The POP as a function of LWP is shown in the first column of Fig. 6a. The POP increases with LWP and a more rapid increase is seen over region $\mathrm{C}$. In REF, POP is $<20 \%$ for typical LWP values $\left(<300 \mathrm{~g} \mathrm{~m}^{-2}\right.$, occurring at $96 \%$ frequency) over region $\mathrm{P}$, while POP values are distinctly larger ( $\sim 10 \%$ and $20 \%$ larger during day and night, respectively) over regions $\mathrm{C}$ than $\mathrm{P}$ for typical LWP values.

Oceanic emissions facilitate rain formation as indicated by the higher POP in REF than in OOCE. When evaluated using POP, this effect is more pronounced over the polluted region $\left(\mathrm{POP}_{\text {ref }}-\mathrm{POP}_{0 \mathrm{OCE}}=-1 \%\right.$ to $-7 \%$ for LWP of 100 $\left.300 \mathrm{~g} \mathrm{~m}^{-2}\right)$ than over the clean region $\left(\mathrm{POP}_{\text {ref }}-\mathrm{POP}_{0 \mathrm{OCE}}=\right.$ $-1 \%$ to $-3 \%$ for LWP of $100-300 \mathrm{~g} \mathrm{~m}^{-2}$ ). When evaluated using rain susceptibility, oceanic emissions also have a larger effect of facilitating rain formation over the polluted region $\mathrm{P}(-0.6)$ than over region $\mathrm{C}(\sim 0.0)$. The stronger effect of oceanic emissions on the surface precipitation frequency and precipitation rate over region $\mathrm{P}$ is consistent with the stronger $N_{\mathrm{d}}$ suppression effect by sea-salt particles over region P discussed earlier.
Anthropogenic emissions suppress rain formation and reduce POP in both regions $\mathrm{P}$ and $\mathrm{C}$. Over region $\mathrm{P}$, regional anthropogenic emissions reduce POP by $2-12 \%$ (for LWP of $100-300 \mathrm{~g} \mathrm{~m}^{-2}$ ) in REF compared to that of OANT, and increased anthropogenic emissions reduce POP by $2-15 \%$ from that of REF. The increased anthropogenic emissions have a much larger rain suppression effect over region $\mathrm{C}$, where reductions in POP for 5ANT relative to REF are 8 $30 \%$ and $18-26 \%$ during day and night, respectively. This is consistent with the larger surface precipitation reduction in region $\mathrm{C}\left(\Delta R=-0.384 \mathrm{~mm} \mathrm{day}^{-1}\right)$ compared to region $\mathrm{P}\left(\Delta R=-0.022 \mathrm{~mm} \mathrm{day}^{-1}\right)$. Over region $\mathrm{C}$, the significant precipitation reduction could also lead to reduced evaporative cooling below clouds which, in addition to the large increase in cloud-top entrainment rate, contributes to a less hu$\operatorname{mid}\left(\Delta q_{\mathrm{v}}=-0.2 \mathrm{~g} \mathrm{~kg}^{-1}\right)$ and warmer $(\Delta T=0.2 \mathrm{~K}) \mathrm{MBL}$.

The larger precipitation inhibition for ScaledEmis over region $\mathrm{C}$ is partially related to the prolonged aerosol lifetime due to an increase in in-cloud wet-scavenging timescale $(\tau)$. The wet-scavenging timescale for $N_{\text {acc }}$ in the MBL is calculated is calculated using:

$\tau=\frac{\sum_{i, j, k, n} \Delta x \Delta y \Delta z_{i, j, k, n}\left(N_{\mathrm{i}_{i, j, k, n}}+N_{\mathrm{c}_{i, j, k, n}}\right)}{\sum_{i, j, k, n} \Delta x \Delta y \Delta z_{i, j, k, n} \lambda_{i, j, k, n} N_{\mathrm{c}_{i, j, k, n}}}$, 
where $N_{\mathrm{i}_{i, j, k, n}}$ and $N_{\mathrm{c}_{i, j, k, n}}$ are number concentrations of interstitial and cloud-borne accumulation mode particles, respectively; $\lambda_{i, j, k, n}$ is the removal rate for cloud water $\left(\mathrm{s}^{-1}\right)$, which is equal to the (normalized) removal rate for cloudborne aerosol in the model. The $\Delta x$ and $\Delta y$ are horizontal grid spacings; $\Delta z$ is the vertical grid spacing; $i$ and $j$ are horizontal grid indexes; $k$ is the vertical layer index within MBL; and $n$ is the index for hourly outputs. Note that this neglects below-cloud wet-scavenging, but it is negligible for accumulation-mode number.

Wet scavenging is the dominant removal process of submicron aerosols over the clean region, so the wet scavenging timescale is a good approximation to aerosol lifetime over this region. Over region $\mathrm{C}$, with the increased anthropogenic emissions (ScaledEmis), the wet scavenging timescale increases from 2.1 to 4.8 days, more than doubling that of the $\mathrm{REF}$ simulation over region $\mathrm{C}$. The prolonged aerosol lifetime due to slower wet scavenging is a positive feedback within the system (i.e., more emissions $\rightarrow$ more $\mathrm{CCN} \rightarrow$ less precipitation $\rightarrow$ even more $\mathrm{CCN}$ ).

The day and night differences in POP are small $\left(\mathrm{POP}_{\text {night }}-\mathrm{POP}_{\text {day }}<2 \%\right)$ over region $\mathrm{P}$, and they are much larger over region $\mathrm{C}\left(\mathrm{POP}_{\text {night }}-\mathrm{POP}_{\text {day }}=10-20 \%\right.$ for $\mathrm{LWP}>100 \mathrm{~g} \mathrm{~m}^{-2}$ ). This larger day-night difference over region $\mathrm{C}$ corresponds to the larger amplitude of the surface precipitation diurnal cycle there $\left(R_{\max }-R_{\min }=\right.$ $0.836 \mathrm{~mm} \mathrm{day}^{-1}$, with $R_{\max }=1.06 \mathrm{~mm} \mathrm{day}^{-1}$ at 05:00 LST and $R_{\min }=0.134$ day $^{-1}$ at 14:00 LST). The larger day-night differences in precipitation amount and precipitation frequency could be due to the stronger nocturnal convection driven by cloud-top cooling over region $\mathrm{C}$ compared to region $\mathrm{P}$.

Cloud effective radius, $r_{\mathrm{e}}$, has been used to characterize the precipitation capacity of clouds. Previous studies (e.g., Freud and Rosenfeld, 2012; Pinsky and Khain, 2002; Rosenfeld et al., 2002) concluded that an $r_{\mathrm{e}}$ value of $14-15 \mu \mathrm{m}$ is necessary to produce precipitation that is detectable by radar. As shown in the middle columns of Fig. 6, region $\mathrm{C}$ has a broader distribution of $r_{\mathrm{e}}$, and over both regions the POP increases sharply with the increase in $r_{\mathrm{e}}$ once a threshold $r_{\mathrm{e}}$ $(\sim 12 \mu \mathrm{m}$ in REF) is reached. There is no explicit threshold effective radius applied in the autoconversion parameterization (Khairoutdinov and Kogan, 2000), but the dependence on $Q_{\mathrm{c}}$ and $N_{\mathrm{c}}$ helps to produce a sharp increase in probability of precipitation (POP) near $\sim 12$ microns. With the same $r_{\mathrm{e}}$ value, $\mathrm{POP}$ is larger during the night than during the day, although the day and night POP- $r_{\mathrm{e}}$ relationships resemble each other. Over both regions, anthropogenic aerosols change the POP- $r_{\mathrm{e}}$ relationships, and a more rapid increase in POP with $r_{\mathrm{e}}$ is seen in the 5ANT case compared to the 0ANT case. The threshold $r_{\mathrm{e}}$, above which the POP starts to increase rapidly with $r_{\mathrm{e}}$, is also smaller in 5ANT. This indicates the significance of the enhanced anthropogenic emissions in modifying rain processes through changing droplet size spectra.
In stratocumulus clouds, cloud thickness and precipitation are tightly related (e.g., Wang and Feingold, 2009a; Wood, 2007). Region $C$ has more frequent occurrence of thick clouds $(D>400 \mathrm{~m})$, and POP over both regions $\mathrm{P}$ and $\mathrm{C}$ has a distinct, sharp increasing tendency with increasing cloud thickness for thick clouds. Similar to LWP, clouds with the same thickness have larger POP at night than during the day. Associated with stronger convective mixing driven by cloud-top radiative cooling, the day and night differences are more distinct over region $\mathrm{C}(\sim 16 \%$ for $D<500 \mathrm{~m})$ than over region $\mathrm{P}(1-11 \%$ for $D<500 \mathrm{~m})$.

Simulated precipitation amounts tend to vary with the selection of cloud microphysics schemes (Boutle and Abel, 2012; Saide et al., 2012). Validation of the simulated precipitation is complicated by spatial variability and uncertainties associated with measurements and derivation approaches. The longitudinal gradient in precipitation is well captured in REF compared to that of observations during VOCALSREx (Q. Yang et al., 2011). The mean simulated near-surface precipitation rate over the remote region $\left(0.07 \mathrm{~mm} \mathrm{~d}^{-1}\right.$ for $78-85^{\circ} \mathrm{W}$ in $\mathrm{REF}$ ) is in good agreement with the mean radar-derived rain rate at $100 \mathrm{~m}$ height $\left(0.06 \mathrm{~mm} \mathrm{~d}^{-1}\right.$ for $80-85^{\circ} \mathrm{W}$; Bretherton et al., 2010b). The mean near-surface ( $\sim 200 \mathrm{~m}$ above the ocean surface) rain rates compared well with airborne 2-D-cloud (2-D-C) derived rain rates when 75 th percentile is used, although they are considerably underestimated when the mean value is used due to the underprediction of occasional relatively heavy rain (Bretherton et al., 2010b; Q. Yang et al., 2011). We expect that the precipitation frequency response to emissions changes and rain susceptibility over regions $\mathrm{P}$ and $\mathrm{C}$ are less affected by this possible bias than the simulated precipitation rate.

\subsection{Changes in energy fluxes due to anthropogenic and oceanic aerosols}

Aerosol and clouds impact the radiative forcing of the atmosphere. At the surface, anthropogenic aerosols have overall cooling effects and addition of sea-salt aerosols leads to surface warming over the SEP. As shown in Fig. 7, the surface shortwave aerosol forcing (net of direct and indirect effects) is the dominant forcing; it is larger than net changes in surface longwave, latent heat, and sensible heat fluxes due to aerosols. The net shortwave forcing from regional anthropogenic and ocean emissions varies from a net cooling effect near the coast to a net warming effect over the remote ocean. Over region $\mathrm{P}$, where the direct and first indirect effect of aerosols dominate, the changes in surface shortwave fluxes due to regional anthropogenic aerosols is $-20 \mathrm{~W} \mathrm{~m}^{-2}$ (15\% of mean aerosol and cloud shortwave forcing [ACSF] in REF; $5 \%$ albedo increase), and this forcing is reduced by $45 \%$ due to regional oceanic emissions. The shortwave forcing from regional anthropogenic emissions over region I is much smaller in magnitude $\left(\sim-3.9 \mathrm{~W} \mathrm{~m}^{-2}\right)$, which is outweighed by the increase in shortwave fluxes due to the 

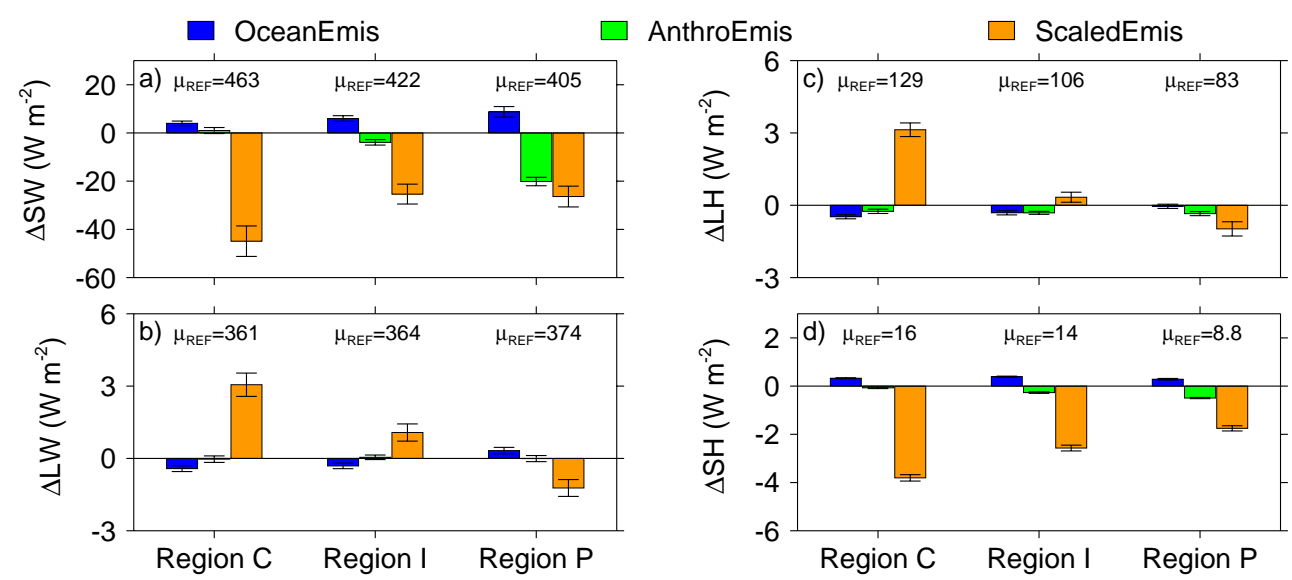

Fig. 7. Same as in Fig. 2, but for responses in mean surface energy fluxes including downward shortwave (SW, panel a), downward longwave (LW, panel b), latent heat (LH, panel c), and sensible heat (SH; panel d) to regional oceanic (OceanEmis, blue), anthropogenic (AnthroEmis, green), and enhanced anthropogenic (ScaledEmis, orange) emissions. Note the different vertical axis scales.

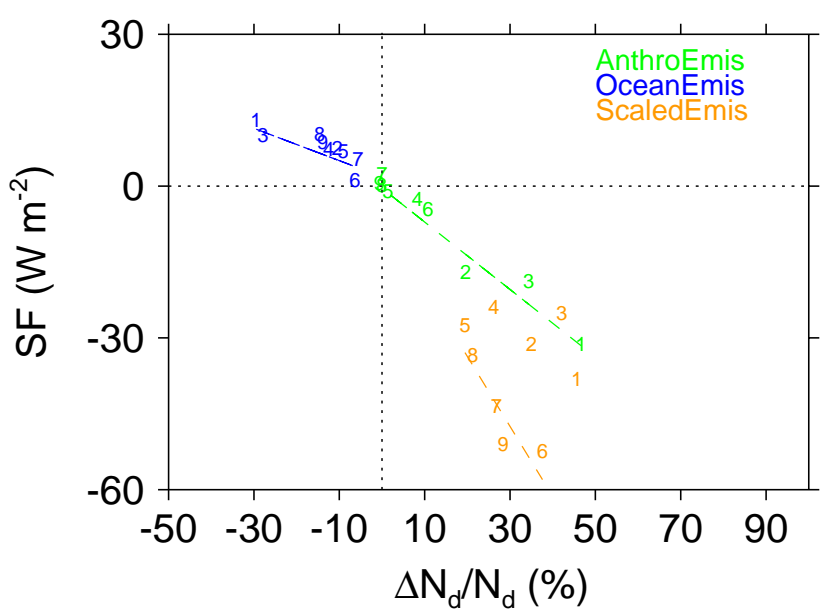

Fig. 8. Relationships between mean relative changes in droplet number concentrations and mean surface shortwave forcings (SF) due to ocean emissions (OceanEmis, blue), anthropogenic emissions (AnthroEmis, green), and scaled anthropogenic emissions (ScaledEmis, orange) within the model domain for the 9 regions defined in Fig. 1. The green and blue best fit lines are based on the green and blue data points, respectively, and the orange color line is based on orange data points for regions 5-9 only.

regional oceanic emissions $\left(6.0 \mathrm{~W} \mathrm{~m}^{-2}\right)$. Over region $\mathrm{C}$, regional ocean emissions lead to a $4.0 \mathrm{~W} \mathrm{~m}^{-2}$ increase in surface shortwave flux, and note that the anthropogenic impact $\left(1 \mathrm{~W} \mathrm{~m}^{-2}\right)$ over this region is not statistically different from 0 (at the $5 \%$ significance level).

The increased anthropogenic emissions (ScaledEmis) exert significant surface cooling with net (direct + indirect) shortwave forcings (SF) of -26 (19\% of ACSF in REF; $6.5 \%$ albedo increase), -25 (18\% of ACSF; $6.0 \%$ albedo increase), and $-45 \mathrm{~W} \mathrm{~m}^{-2}$ (33\% of ACSF; $9.7 \%$ albedo increase) for regions $\mathrm{P}, \mathrm{I}$, and $\mathrm{C}$, respectively. This is due to the large changes in cloud optical properties $\left(r_{\mathrm{e}}\right.$ and COD), macro-physical properties $\left(Z_{\mathrm{t}}, Z_{\mathrm{b}}, D_{\text {cld }}, \mathrm{LWP}\right.$, and $\left.f_{\text {low }}\right)$, and precipitation with the enhanced anthropogenic emissions. The surface shortwave flux changes due to OceanEmis over the polluted region (region $\mathrm{P}$ ) is more than double that of the clean region (region C). This is associated with stronger droplet activation suppression by sea-salt particles in the polluted environment, leading to optically thinner clouds (see COD in Fig. 2f).

Figure 8 shows mean net (including direct and indirect effects) shortwave aerosol forcings at the surface versus relative change in $N_{\mathrm{d}}$ due to emission changes for the 9 regions shown in Fig. 1. The mean changes in surface shortwave fluxes over region $P$ are approximately a linear function of the relative change in $N_{\mathrm{d}}$ due to regional anthropogenic emissions (AnthroEmis; a correlation coefficient [corr] of $-0.98)$. With the enhanced anthropogenic regional emissions (ScaledEmis), regions closer to the coast (regions 1-4; regions 3 and 4 are regions $\mathrm{P}$ and I) have shortwave forcing responses that line up around the best-fit line for the AnthroEmis, indicating similar sensitivity. However, over remote regions 5-9 (note that region 6 is region C), the shortwave forcing responses decrease more sharply with the relative change in $N_{\mathrm{d}}$, with the best-fit line (based on regions 5-9, corr $=-0.90$ ) having a much steeper slope (Fig. 8), indicating larger sensitivity of shortwave forcing to anthropogenic aerosols as a result of stronger aerosol-cloud interactions. The mean shortwave response to oceanic emissions in each region is opposite in sign to that of anthropogenic aerosols. The response is also roughly linear ( $c o r r=-0.82$ ) to the relative changes in cloud droplet number concentrations. The responses of surface shortwave fluxes to oceanic versus anthropogenic aerosol perturbations are different in sign, and their sensitivity to anthropogenic perturbations over clean versus polluted environment also is different in strength. Therefore, 
the representation of oceanic emissions are important for the accurate estimation of anthropogenic aerosol impacts on radiative balances over both polluted and clean marine stratocumulus regions in climate models.

The downward surface longwave radiation flux is not sensitive to AnthroEmis. With ScaledEmis, the longwave flux varies from negative $\left(-1.2 \mathrm{~W} \mathrm{~m}^{-2}\right)$ over region $\mathrm{P}$ to positive (1.1 and $3.3 \mathrm{~W} \mathrm{~m}^{-2}$ ) over regions I and $\mathrm{C}$, corresponding to the changes in $f_{\text {low }}$ shown in Fig. 3e. The sensitivity of the longwave flux to oceanic perturbations (OceanEmis) is small and always in opposite sign to its sensitivity to anthropogenic perturbation (AnthroEmis), which is also similar to the responses of $f_{\text {low }}$ in Fig. 3e.

The changes in surface latent heat (Fig. 7c) and sensible heat fluxes (Fig. 7d) due to regional anthropogenic and oceanic aerosols are small $\left(<5 \%\right.$ and $<0.5 \mathrm{~W} \mathrm{~m}^{-2}$ in magnitude). With the ScaledEmis, surface fluxes over region $\mathrm{C}$ have noticeable response: $-24 \%\left(-3.8 \mathrm{~W} \mathrm{~m}^{-2}\right)$ for sensible heat and $2 \%\left(3.1 \mathrm{~W} \mathrm{~m}^{-2}\right)$ for latent heat. The small decrease in sensible heat flux and increase in latent heat flux with ScaledEmis over region $\mathrm{C}$ are due to a warmer (by $0.2 \mathrm{~K}$ ) and drier (of $0.2 \mathrm{~g} \mathrm{~kg}^{-1}$ ) MBL and a slight increase (of $0.1 \mathrm{~m} \mathrm{~s}^{-1}$ ) in surface wind speed.

\section{Summary and conclusion}

Changes in aerosol, cloud properties, and energy fluxes over the Southeast Pacific (SEP) due to regional anthropogenic and oceanic emissions are estimated by comparing WRFChem simulations under different emission scenarios. Simulations are conducted at a cloud-system resolving scale for the month-long VOCALS-REx period (15 October-16 November 2008). Conclusions and implications from this study are based on the period-averaged responses of aerosols, clouds, and radiation to emission changes relative to the estimated Oct-Nov 2008 emissions. Three regions $\left(\sim 5^{\circ}\right.$ longitude by $5^{\circ}$ latitude) with relatively polluted (region P), intermediate (region I), and clean (region C) conditions are selected for detailed analysis. Region I has intermediate anthropogenic impacts, and its response is typically between those of regions $\mathrm{P}$ and $\mathrm{C}$, thus the discussion below focuses on regions $\mathrm{P}$ and $\mathrm{C}$ only.

The near-coast region $\mathrm{P}$ is relatively polluted with number concentrations of accumulation mode aerosols near surface $\left(N_{\mathrm{a}}\right)$ and cloud droplets at cloud-top $\left(N_{\mathrm{d}}\right)$ of 384 and $133 \mathrm{~cm}^{-3}$, respectively. Regional (within model domain) anthropogenic and oceanic emissions lead to comparable (34\% vs. $20 \%$ ) increases in CCN (at $0.1 \%$ supersaturation) number concentrations $\left(N_{\mathrm{CCN}}\right)$ at $970 \mathrm{hPa}$ over this region. This region is also characterized by low surface precipitation rates (mean of $0.07 \mathrm{~mm} \mathrm{day}^{-1}$ ), stronger suppression of non-seasalt particle activation by sea-salt particles, an important first indirect effect of aerosols, and limited impact of aerosols associated with anthropogenic emissions on clouds. Over this region, simulated aerosol size distributions also indicate that the addition of sea-salt particles inhibits the growth of fine non-sea-salt particles (dry diameter $<0.078 \mu \mathrm{m}$ ) to accumulation mode size.

The remote region $\mathrm{C}$ is relatively clean $\left(N_{\mathrm{a}}=221 \mathrm{~cm}^{-3}\right.$; $N_{\mathrm{d}}=71 \mathrm{~cm}^{-3}$ ) and by contrasting 0ANT and REF simulations, it is found that regional anthropogenic emissions (AnthroEmis) have a negligible impact over this region. This region is also characterized by the importance of non-regional sources to $N_{\mathrm{acc}}$ and $N_{\mathrm{d}}$ (i.e., advected from the lateral boundaries of the model domain), significant surface precipitation (mean of $0.6 \mathrm{~mm} \mathrm{day}^{-1}$ ), and strong aerosol-cloudprecipitation-radiation interactions when perturbed with a five-fold increase in anthropogenic emissions. The changes in $N_{\mathrm{acc}}$ and $N_{\mathrm{d}}$ are not linear functions of the changes in emissions due to the highly non-linear aerosol and cloud microphysical processes.

Over the ocean, the background sea-salt particles influence the magnitude of the cloud response to anthropogenic aerosol perturbations. The sensitivity of cloud properties, precipitation, and the surface and top-of-atmosphere shortwave fluxes to regional anthropogenic aerosols is opposite in sign to their sensitivity to oceanic aerosol perturbations (see Table 2 for a summary of changes in cloud properties). In the polluted region P, a $33 \%$ increase in $N_{\text {acc }}$ due to regional anthropogenic emissions leads to a moderate increase in net (direct + indirect) surface aerosol shortwave forcing ( $15 \%$ of the mean aerosol and cloud SF in REF; $4 \%$ increase in albedo), and $45 \%$ of this effect is counteracted by the warming effect due to oceanic emissions. Due to the varying cloud responses to different emissions (oceanic vs. anthropogenic) and in different regions (clean versus polluted), the representation of regional oceanic aerosols is important for assessing the impacts of anthropogenic perturbations on the regional surface energy balance.

In the clean region, cloud properties have high sensitivity to a moderate increase in aerosol concentrations $\left(\Delta N_{\mathrm{acc}}=\right.$ $\left.46 \mathrm{~cm}^{-3},[21 \%] ; \Delta N_{\mathrm{CCN}}=13 \mathrm{~cm}^{-3},[25 \%]\right)$ produced by the five-fold increase in regional anthropogenic emissions. Partially associated with the more efficient aerosol activation in a clean environment, the response in cloud micro- and optical properties is large (see Table 2 for a summary). The clean region is heavily drizzling and the important role of drizzle in modifying distributions of water and static energy as well as aerosol sources (e.g., entrainment) and sinks in the MBL is tightly related to the high sensitivity over this region. The amount of precipitation reduction due to the enhanced anthropogenic emissions is significant over the remote region C. The reduction in precipitation also prolongs aerosol lifetime in the MBL (4.8 versus 2.1 days), which, in turn, further reduces precipitation. Therefore, the aerosol impact on precipitation is amplified by the positive feedback of precipitation on aerosols. The positive feedback leads to increased sensitivity of clouds and precipitation to emission changes, and thus a stronger ACI regime. The high sensitivity over this 
Table 2. The mean responses and aerosol-cloud interaction indices associated with regional oceanic (OceanEmis), regional anthropogenic (AnthroEmis), and enhanced regional anthropogenic emissions (ScaledEmis).

\begin{tabular}{lrrrrrrr}
\hline \multirow{2}{*}{ Parameter } & Region & \multicolumn{2}{c}{ OceanEmis } & \multicolumn{2}{c}{ AnthroEmis } & \multicolumn{2}{c}{ ScaledEmis } \\
\cline { 3 - 8 } & & Response & $\mathrm{ACI}_{\mathrm{CCN}}(Y)$ & Response & $\mathrm{ACI}_{\mathrm{CCN}}(Y)$ & Response & $\mathrm{ACI}_{\mathrm{CCN}}(Y)$ \\
\hline \multirow{2}{*}{$\Delta N_{\mathrm{d}}$} & $\mathrm{P}$ & $-27 \%$ & -1.09 & $34 \%$ & 1.00 & $72 \%$ & 0.83 \\
& $\mathrm{C}$ & $-3 \%$ & -0.09 & $0 \%$ & - & $36 \%$ & 1.36 \\
\hline \multirow{2}{*}{$\Delta r_{\mathrm{e}}$} & $\mathrm{P}$ & $5 \%$ & 0.24 & $-10 \%$ & -0.25 & $-21 \%$ & -0.37 \\
& $\mathrm{C}$ & $1 \%$ & 0.03 & - & - & $-32 \%$ & -1.71 \\
\hline \multirow{2}{*}{$\Delta \mathrm{COD}$} & $\mathrm{P}$ & $-9 \%$ & -0.42 & $14 \%$ & 0.36 & $21 \%$ & 0.29 \\
& $\mathrm{C}$ & $-4 \%$ & -0.07 & - & - & $54 \%$ & 1.90 \\
\hline \multirow{2}{*}{$\Delta Z_{\mathrm{t}}$} & $\mathrm{P}$ & $-1 \%$ & -0.06 & $1 \%$ & 0.03 & $6 \%$ & 0.10 \\
\hline \multirow{2}{*}{$\Delta D_{\mathrm{cld}}$} & $\mathrm{C}$ & $-1 \%$ & -0.02 & - & - & $13 \%$ & 0.56 \\
\hline \multirow{2}{*}{$\Delta \mathrm{LWP}$} & $\mathrm{P}$ & $0 \%$ & -0.02 & $0 \%$ & 0.01 & $0 \%$ & 0.00 \\
& $\mathrm{C}$ & $0 \%$ & -0.01 & - & - & $11 \%$ & 0.48 \\
\hline
\end{tabular}

region is also related to a higher entrainment rate increase (16\% over region $\mathrm{C}$ versus $3 \%$ at night over region $\mathrm{P}$ ) due to increased anthropogenic aerosols. Over the clean region, the enhanced anthropogenic emissions lead to an increase in LWP due to the reduced precipitation (as a cloud water sink) and increased surface moisture flux that outweighs the decrease in LWP due to the increased entrainment of dry air.

With the enhanced anthropogenic emissions, aerosolcloud-precipitation interactions over the clean region $\mathrm{C}$ have a strong diurnal cycle with the strongest interactions at night. Based on the simulated mean diurnal cycles, strong solar heating during the day leads to more frequent decoupling of the cloud and sub-cloud layers (diurnal maximum of $\sim 50 \%$ ), reduced precipitation (daily minimum of $0.1 \mathrm{~mm} \mathrm{day}^{-1}$ ), thin clouds (daily minimum LWP of $\sim 42 \mathrm{~g} \mathrm{~m}^{-2}$ ) near 12:00-15:00 LST, and reduced sensitivity of cloud properties to emissions during the daytime. Increased anthropogenic emissions are shown to enhance the daytime decoupling frequency by $5-10 \%$. The reduced cloud and precipitation sensitivity to emissions during the day over the clean region is also linked to a diurnal $N_{\mathrm{d}}$ minimum ( $\sim 35 \%$ lower than the diurnal mean).

The high sensitivity to increased anthropogenic emissions over the clean region suggests that the perturbation of the energy balance from increased anthropogenic emissions are larger in the more susceptible clean environment than in already polluted environment and is larger than possible from first indirect effect alone. Compared to the polluted region, the large response to changes in anthropogenic aerosols over the remote region has implications towards slow manifolds and multiple cloud regimes in stratocumulus clouds (Bretherton et al., 2010a).
Through quantifying and contrasting the response of cloud/precipitation to anthropogenic and natural aerosols over both clean and polluted marine regions we have presented a relatively complete picture of aerosol-cloud interactions over the Southeast Pacific using WRF-Chem, which sets the stage for future aerosol-cloud regional modeling studies over this region. Our results show the importance of natural aerosol in accurately quantifying anthropogenic forcing within a regional modeling framework. The simulated cloud responses and feedbacks to aerosol perturbations are in general agreement with those from previous studies using process-based models, although studies using process-based models in the literature are not directly comparable to ours because of different aerosol perturbations, our use of current emissions and varying synoptic-scale meteorological conditions. This strengthens the credibility of the WRF-Chem regional model with prognostic aerosols and coupled aerosolcloud-radiation processes for simulating aerosol-cloud interactions. We highlight the impacts of anthropogenic emissions on the regional forcing in realistic meteorological conditions, which helps increase the understanding of aerosol effects on climate over the SEP where there are large longitudinal aerosol gradients and the emission sources are rich in sulfur. Our approach of using emission-to-forcing measures and using both relative and absolute responses also facilitates communication between the science community and decision makers.

Acknowledgements. We would like to thank Julia Flaherty for the internal review and Songyou Hong for helpful discussions regarding the YSU scheme. Funding for this research has been provided by the US National Oceanic and Atmospheric Administration (NOAA) Atmospheric Composition and Climate 
Program (NA10AANRG0083/56091). Pacific Northwest National Laboratory is operated by Battelle Memorial Institute for the US Department of Energy under Contract No. DE-AC05-76RL01830.

Edited by: R. Wood

\section{References}

Abdul-Razzak, H. and Ghan, S. J.: A parameterization of aerosol activation 2. Multiple aerosol types, J. Geophys. Res., 105, 68376844, doi:10.1029/1999JD901161, 2000.

Ackerman, A. S., Toon, O. B., Stevens, D. E., and Coakley, J. A.: Enhancement of cloud cover and suppression of nocturnal drizzle in stratocumulus polluted by haze, Geophys. Res. Lett., 30, 1381, doi:10.1029/2002g1016634, 2003.

Ackerman, A. S., Kirkpatrick, M. P., Stevens, D. E., and Toon, O. B.: The impact of humidity above stratiform clouds on indirect aerosol climate forcing, Nature, 432, 1014-1017, doi:10.1038/Nature03174, 2004.

Albrecht, B. A.: Aerosols, Cloud Microphysics, and Fractional Cloudiness, Science, 245, 1227-1230, 1989.

Allen, G., Coe, H., Clarke, A., Bretherton, C., Wood, R., Abel, S. J., Barrett, P., Brown, P., George, R., Freitag, S., McNaughton, C., Howell, S., Shank, L., Kapustin, V., Brekhovskikh, V., Kleinman, L., Lee, Y.-N., Springston, S., Toniazzo, T., Krejci, R., Fochesatto, J., Shaw, G., Krecl, P., Brooks, B., McMeeking, G., Bower, K. N., Williams, P. I., Crosier, J., Crawford, I., Connolly, P., Allan, J. D., Covert, D., Bandy, A. R., Russell, L. M., Trembath, J., Bart, M., McQuaid, J. B., Wang, J., and Chand, D.: South East Pacific atmospheric composition and variability sampled along $20^{\circ} \mathrm{S}$ during VOCALS-REx, Atmos. Chem. Phys., 11, 5237-5262, doi:10.5194/acp-11-5237-2011, 2011.

Baker, M. B. and Charlson, R. J.: Bistability of CCN Concentrations and Thermodynamics in the Cloud-topped Boundary-Layer, Nature, 345, 142-145, 1990.

Barnard, J. C., Fast, J. D., Paredes-Miranda, G., Arnott, W. P., and Laskin, A.: Technical Note: Evaluation of the WRF-Chem "Aerosol Chemical to Aerosol Optical Properties" Module using data from the MILAGRO campaign, Atmos. Chem. Phys., 10, 7325-7340, doi:10.5194/acp-10-7325-2010, 2010.

Berner, A. H., Bretherton, C. S., and Wood, R.: Large-eddy simulation of mesoscale dynamics and entrainment around a pocket of open cells observed in VOCALS-REx RF06, Atmos. Chem. Phys., 11, 10525-10540, doi:10.5194/acp-11-10525-2011, 2011.

Blomquist, B. W., Fairall, C. W., Huebert, B. J., Kieber, D. J., and Westby, G. R.: DMS sea-air transfer velocity: Direct measurements by eddy covariance and parameterization based on the NOAA/COARE gas transfer model, Geophys. Res. Lett., 33, L07601, doi:10.1029/2006g1025735, 2006.

Boutle, I. A. and Abel, S. J.: Microphysical controls on the stratocumulus topped boundary-layer structure during VOCALS-REx, Atmos. Chem. Phys., 12, 2849-2863, doi:10.5194/acp-12-28492012, 2012.

Bretherton, C. S. and Wyant, M. C.: Moisture transport, lowertropospheric stability, and decoupling of cloud-topped boundary layers, J. Atmos. Sci., 54, 148-167, 1997.

Bretherton, C. S., Blossey, P. N., and Uchida, J.: Cloud droplet sedimentation, entrainment efficiency, and subtropi- cal stratocumulus albedo, Geophys. Res. Lett., 34, L03813, doi:10.1029/2006g1027648, 2007.

Bretherton, C. S., Uchida, J., and Blossey, P. N.: Slow manifolds and multiple equilibria in stratocumulus-capped boundary layers, J. Adv. Model. Earth Syst., 2, 14, 20 pp. doi:10.3894/JAMES.2010.2.14, 2010a.

Bretherton, C. S., Wood, R., George, R. C., Leon, D., Allen, G., and Zheng, X.: Southeast Pacific stratocumulus clouds, precipitation and boundary layer structure sampled along $20^{\circ} \mathrm{S}$ during VOCALS-REx, Atmos. Chem. Phys., 10, 10639-10654, doi:10.5194/acp-10-10639-2010, 2010 .

Chand, D., Hegg, D. A., Wood, R., Shaw, G. E., Wallace, D., and Covert, D. S.: Source attribution of climatically important aerosol properties measured at Paposo (Chile) during VOCALS, Atmos. Chem. Phys., 10, 10789-10801, doi:10.5194/acp10-10789-2010, 2010.

Clarke, A. D., Owens, S. R., and Zhou, J. C.: An ultrafine seasalt flux from breaking waves: Implications for cloud condensation nuclei in the remote marine atmosphere, J. Geophys. Res.Atmos., 111, D06202, doi:10.1029/2005jd006565, 2006.

Chapman, E. G., Gustafson Jr., W. I., Easter, R. C., Barnard, J. C., Ghan, S. J., Pekour, M. S., and Fast, J. D.: Coupling aerosolcloud-radiative processes in the WRF-Chem model: Investigating the radiative impact of elevated point sources, Atmos. Chem. Phys., 9, 945-964, doi:10.5194/acp-9-945-2009, 2009.

Charlson, R. J., Lovelock, J. E., Andreae, M. O., and Warren, S. G.: Oceanic Phytoplankton, Atmospheric Sulfur, Cloud Albedo and Climate, Nature, 326, 655-661, 1987.

Chen, Y.-C., Xue, L., Lebo, Z. J., Wang, H., Rasmussen, R. M., and Seinfeld, J. H.: A comprehensive numerical study of aerosolcloud-precipitation interactions in marine stratocumulus, Atmos. Chem. Phys., 11, 9749-9769, doi:10.5194/acp-11-9749-2011, 2011.

de Szoeke, S. P., Fairall, C. W., Wolfe, D. E., Bariteau, L., and Zuidema, P.: Surface Flux Observations on the Southeastern Tropical Pacific Ocean and Attribution of SST Errors in Coupled Ocean-Atmosphere Models, J. Climate, 23, 4152-4174, doi:10.1175/2010jcli3411.1, 2010.

Fast, J. D., Gustafson, W. I., Easter, R. C., Zaveri, R. A., Barnard, J. C., Chapman, E. G., Grell, G. A., and Peckham, S. E.: Evolution of ozone, particulates, and aerosol direct radiative forcing in the vicinity of Houston using a fully coupled meteorology-chemistry-aerosol model, J. Geophys. Res.-Atmos., 111, D21305, doi:10.1029/2005jd006721, 2006.

Fast, J. D., Gustafson Jr., W. I., Berg, L. K., Shaw, W. J., Pekour, M., Shrivastava, M., Barnard, J. C., Ferrare, R. A., Hostetler, C. A., Hair, J. A., Erickson, M., Jobson, B. T., Flowers, B., Dubey, M. K., Springston, S., Pierce, R. B., Dolislager, L., Pederson, J., and Zaveri, R. A.: Transport and mixing patterns over Central California during the carbonaceous aerosol and radiative effects study (CARES), Atmos. Chem. Phys., 12, 1759-1783, doi:10.5194/acp-12-1759-2012, 2012.

Feingold, G., Cotton, W. R., Kreidenweis, S. M., and Davis, J. T.: The impact of giant cloud condensation nuclei on drizzle formation in stratocumulus: Implications for cloud radiative properties, J. Atmos. Sci., 56, 4100-4117, 1999.

Feingold, G., Remer, L. A., Ramaprasad, J., and Kaufman, Y. J.: Analysis of smoke impact on clouds in Brazilian biomass burning regions: An extension of Twomey's approach, J. Geophys. 
Res., 106, 22907-22922, 2001.

Feingold, G., Eberhard, W. L., Veron, D. E., and Previdi, M.: First measurements of the Twomey indirect effect using ground-based remote senors, Geophys. Res. Lett., 30, 1287, doi:10.1029/2002GL016633, 2003.

Freud, E. and Rosenfeld, D.: Linear relation between convective cloud drop number concentration and depth for rain initiation, J. Geophys. Res.-Atmos., 117, D02207, doi:10.1029/2011jd016457, 2012.

Gao, Y., Liu, X., Zhao, C., and Zhang, M.: Emission controls versus meteorological conditions in determining aerosol concentrations in Beijing during the 2008 Olympic Games, Atmos. Chem. Phys., 11, 12437-12451, doi:10.5194/acp-11-12437-2011, 2011.

Ghan, S. J., Guzman, G., and Abdul-Razzak, H.: Competition between sea salt and sulfate particles as cloud condensation nuclei, J. Atmos. Sci., 55, 3340-3347, 1998.

Gong, S. L., Barrie, L. A., and Blanchet, J. P.: Modeling sea-salt aerosols in the atmosphere .1. Model development, J. Geophys. Res.-Atmos., 102, 3805-3818, 1997.

Grell, G. A., Peckham, S. E., Schmitz, R., McKeen, S. A., Frost, G., Skamarock, W. C., and Eder, B.: Fully coupled "online" chemistry within the WRF model, Atmos. Environ., 39, 6957-6975, doi:10.1016/j.atmosenv.2005.04.027, 2005.

Gustafson, W. I., Chapman, E. G., Ghan, S. J., Easter, R. C., and Fast, J. D.: Impact on modeled cloud characteristics due to simplified treatment of uniform cloud condensation nuclei during NEAQS 2004, Geophys. Res. Lett., 34, L19809, doi:10.1029/2007g1030021, 2007.

Hawkins, L. N., Russell, L. M., Covert, D. S., Quinn, P. K., and Bates, T. S.: Carboxylic acids, sulfates, and organosulfates in processed continental organic aerosol over the southeast Pacific Ocean during VOCALS-REx 2008, J. Geophys. Res.-Atmos., 115, D13201, doi:10.1029/2009jd013276, 2010.

Hill, A. A., Feingold, G., and Jiang, H. L.: The Influence of Entrainment and Mixing Assumption on Aerosol-Cloud Interactions in Marine Stratocumulus, J. Atmos. Sci., 66, 1450-1464, doi:10.1175/2008jas2909.1, 2009.

Hong, S. Y., Noh, Y., and Dudhia, J.: A new vertical diffusion package with an explicit treatment of entrainment processes, Mon. Weather Rev., 134, 2318-2341, 2006.

Jones, C. R., Bretherton, C. S., and Leon, D.: Coupled vs. decoupled boundary layers in VOCALS-REx, Atmos. Chem. Phys., 11, 7143-7153, doi:10.5194/acp-11-7143-2011, 2011.

Kazil, J., Wang, H., Feingold, G., Clarke, A. D., Snider, J. R., and Bandy, A. R.: Modeling chemical and aerosol processes in the transition from closed to open cells during VOCALS-REx, Atmos. Chem. Phys., 11, 7491-7514, doi:10.5194/acp-11-74912011, 2011.

Khairoutdinov, M., and Y. Kogan: A new cloud physics parameterization in a large-eddy simulation model of marine stratocumulus, Mon. Weather Rev., 128, 229-243, 2000.

Klein, S. A. and Hartmann, D. L.: The seasonal cycle of low stratiform clouds, J. Climate, 6, 1587-1606, 1993.

Kleinman, L. I., Daum, P. H., Lee, Y.-N., Lewis, E. R., Sedlacek III, A. J., Senum, G. I., Springston, S. R., Wang, J., Hubbe, J., Jayne, J., Min, Q., Yum, S. S., and Allen, G.: Aerosol concentration and size distribution measured below, in, and above cloud from the DOE G-1 during VOCALS-REx, Atmos. Chem. Phys., 12, 207223, doi:10.5194/acp-12-207-2012, 2012.
Kogan, Y. L., Mechem, D. B., and Choi, K.: Effects of sea-salt aerosols on precipitation in siumulations of shallow cumulus, J. Atmos. Sci, 69, 463-483, doi:10.1175/JAS-D-11-031.1, 2012.

L'Ecuyer, T. S., Berg, W., Haynes, J., Lebsock, M., and Takemura, T.: Global observations of aerosol impacts on precipitation occurrence in warm maritime clouds, J. Geophys. Res.-Atmos., 114, D09211, doi:10.1029/2008jd011273, 2009.

Loeb, N. G. and Schuster, G. L.: An observational study of the relationship between cloud, aerosol and meteorology in broken low-level cloud conditions, J. Geophys. Res., 113, D14214, doi:10.1029/2007JD009763, 2008.

Lu, M. L. and Seinfeld, J. H.: Study of the aerosol indirect effect by large-eddy simulation of marine stratocumulus, J. Atmos. Sci., 62, 3909-3932, 2005.

Manton, M. J. and Cotton, W. R.: Parameterization of the atmospheric surface layer, J. Atmos. Sci., 34, 331-334, 1977.

Matsui, T., Masunaga, H., Kreidenweis, S. M., Pielke, R. A., Tao, W. K., Chin, M., and Kaufman, Y. J.: Satellite-based assessment of marine low cloud variability associated with aerosol, atmospheric stability, and the diurnal cycle, J Geophys Res-Atmos, 111, D20202, doi:10.1029/2006jd008056, 2006.

Mechem, D. B., Yuter, S. E., and de Szoeke, S. P.: Thermodynamic and aerosol controls in Southeast Pacific Stratocumulus, J. Atmos. Sci., 69, 1250-1266, doi:10.1175/JAS-D-11-0165.1, 2012.

Monahan, E. C., Spiel, D. E., and Davidson, K. L.: A model of marine aerosol generation via whitecaps and wave disruption, in: Oceanic Whitecaps, edited by: Niocail, E. C. M. a. G. M., Reidel, D., Norwell, 167-174, 1986.

Morrison, H., Thompson, G., and Tatarskii, V.: Impact of Cloud Microphysics on the Development of Trailing Stratiform Precipitation in a Simulated Squall Line: Comparison of One- and Two-Moment Schemes, Mon. Weather Rev., 137, 991-1007, doi:10.1175/2008mwr2556.1, 2009.

Nicholls, S.: The Dynamics of Stratocumulus - Aircraft Observations and Comparisons with a Mixed Layer Model, Q. J. Roy. Meteor. Soc., 110, 783-820, 1984.

Nightingale, P. D., Malin, G., Law, C. S., Watson, A. J., Liss, P. S., Liddicoat, M. I., Boutin, J., and Upstill-Goddard, R. C.: In situ evaluation of air-sea gas exchange parameterizations using novel conservative and volatile tracers, Global Biogeochem. Cy., 14, 373-387, 2000.

Noh Y., Gheon, W. G., Hong, S. Y., and Raasch, S.: Improvement of the K-profile model for the planetary boundary layer based on large eddy simulation data, Bound.-Lay. Meteorol., 107, 401427, 2003.

Painemal, D. and Zuidema, P.: Microphysical variability in southeast Pacific Stratocumulus clouds: synoptic conditions and radiative response, Atmos. Chem. Phys., 10, 6255-6269, doi:10.5194/acp-10-6255-2010, 2010.

Penner, J. E., Xu, L., and Wang, M. H.: Satellite methods underestimate indirect climate forcing by aerosols, P. Natl. Acad. Sci. USA, 108, 13404-13408, 2011.

Pincus, R. and Baker, M. B.: Effect of Precipitation on the Albedo Susceptibility of Clouds in the Marine Boundary-Layer, Nature, 372, 250-252, 1994.

Pinsky, M. B. and Khain, A. P.: Effects of in-cloud nucleation and turbulence on droplet spectrum formation in cumulus clouds, Q. J. Roy. Meteor. Soc., 128, 501-533, 2002. 
Qian, Y., Gustafson, W. I., Leung, L. R., and Ghan, S. J.: Effects of soot-induced snow albedo change on snowpack and hydrological cycle in western United States based on Weather Research and Forecasting chemistry and regional climate simulations, J. Geophys. Res.-Atmos., 114, D03108, doi:10.1029/2008jd011039, 2009.

Quaas, J., Ming, Y., Menon, S., Takemura, T., Wang, M., Penner, J. E., Gettelman, A., Lohmann, U., Bellouin, N., Boucher, O., Sayer, A. M., Thomas, G. E., McComiskey, A., Feingold, G., Hoose, C., Kristjánsson, J. E., Liu, X., Balkanski, Y., Donner, L. J., Ginoux, P. A., Stier, P., Grandey, B., Feichter, J., Sednev, I., Bauer, S. E., Koch, D., Grainger, R. G., Kirkevåg, A., Iversen, T., Seland, Ø., Easter, R., Ghan, S. J., Rasch, P. J., Morrison, H., Lamarque, J.-F., Iacono, M. J., Kinne, S., and Schulz, M.: Aerosol indirect effects - general circulation model intercomparison and evaluation with satellite data, Atmos. Chem. Phys., 9, 8697-8717, doi:10.5194/acp-9-8697-2009, 2009.

Raes, F.: Entrainment of free tropospheric aerosols as a regulating mechanism for cloud condensation nuclei in the remote marine boundary layer, J. Geophys. Res., 100, 2893-2903, doi:10.1029/94JD02832, 1995.

Rahn, D. A. and Garreaud, R.: Marine boundary layer over the subtropical southeast Pacific during VOCALS-REx - Part 1: Mean structure and diurnal cycle, Atmos. Chem. Phys., 10, 4491-4506, doi:10.5194/acp-10-4491-2010, 2010.

Rosenfeld, D., Lahav, R., Khain, A., and Pinsky, M.: The role of sea spray in cleansing air pollution over ocean via cloud processes, Science, 297, 1667-1670, doi:10.1126/Science.1073869, 2002.

Saide, P. E., Spak, S. N., Carmichael, G. R., Mena-Carrasco, M. A., Yang, Q., Howell, S., Leon, D. C., Snider, J. R., Bandy, A. R., Collett, J. L., Benedict, K. B., de Szoeke, S. P., Hawkins, L. N., Allen, G., Crawford, I., Crosier, J., and Springston, S. R.: Evaluating WRF-Chem aerosol indirect effects in Southeast Pacific marine stratocumulus during VOCALS-REx, Atmos. Chem. Phys., 12, 3045-3064, doi:10.5194/acp-12-3045-2012, 2012.

Sandu, I., Brenguier, J. L., Geoffroy, O., Thouron, O., and Masson, V.: Aerosol impacts on the diurnal cycle of marine stratocumulus, J. Atmos. Sci., 65, 2705-2718, doi:10.1175/2008jas2451.1, 2008.

Shank, L. M., Howell, S., Clarke, A. D., Freitag, S., Brekhovskikh, V., Kapustin, V., McNaughton, C., Campos, T., and Wood, R.: Organic matter and non-refractory aerosol over the remote Southeast Pacific: oceanic and combustion sources, Atmos. Chem. Phys., 12, 557-576, doi:10.5194/acp-12-557-2012, 2012.

Shin, H. H. and Hong, S.-Y.: Intercomparison of planetary boundary-layer parameterization in the WRF Model for a single day from CASE-99, Boud.-Lay. Meteorol., 139, 261-281, doi:10.1007/s10546-010-9583-z, 2011.

Solomon, S., Qin, D., Manning, M., Chen, Z., Marquis, M., Averyt, K., Tignor, M., and Miller, H. L. (Eds.): IPCC, 2007: Summary for Policymakers, in: Climate Change 2007: The Physical Science Basis. Contribution of Working Group I to the Fourth Assessment Report of the Intergovernmental Panel on Climate Change, Cambridge University Press, Cambridge, UK and New York, NY, USA, 2007.

Sorooshian, A., Feingold, G., Lebsock, M. D., Jiang, H. L., and Stephens, G. L.: On the precipitation susceptibility of clouds to aerosol perturbations, Geophys. Res. Lett., 36, L13803, doi:10.1029/2009g1038993, 2009.
Stevens, B.: Bulk boundary-layer concepts for simplified models of tropical dynamics, Theor. Comp. Fluid Dyn., 20, 279-304, doi:10.1007/S00162-006-0032-Z, 2006.

Stevens, B. and Feingold, G.: Untangling aerosol effects on clouds and precipitation in a buffered system, Nature, 461, 607-613, doi:10.1038/nature08281, 2009.

Stevens, B., Cotton, W. R., Feingold, G., and Moeng C.H.: Large-Eddy simulations of strongly precipitating, shallow, stratocumulus-topped boundary layers, J. Atmos. Sci., 55, 36163638, 1998.

Terai, C. R., Wood, R., Leon, D. C., and Zuidema, P.: Does precipitation susceptibility vary with increasing cloud thickness in marine stratocumulus?, Atmos. Chem. Phys., 12, 4567-4583, doi:10.5194/acp-12-4567-2012, 2012.

Toniazzo, T., Abel, S. J., Wood, R., Mechoso, C. R., Allen, G., and Shaffrey, L. C.: Large-scale and synoptic meteorology in the south-east Pacific during the observations campaign VOCALS-REx in austral Spring 2008, Atmos. Chem. Phys., 11, 4977-5009, http://dx.doi.org/10.5194/acp-11-49772011doi:10.5194/acp-11-4977-2011, 2011.

Twomey, S.: Influence of Pollution on Shortwave Albedo of Clouds, J. Atmos. Sci., 34, 1149-1152, 1977.

Wang, H. and Feingold, G.: Modeling Mesoscale Cellular Structures and Drizzle in Marine Stratocumulus. Part I: Impact of Drizzle on the Formation and Evolution of Open Cells, J. Atmos. Sci., 66, 3237-3256, doi:10.1175/2009jas3022.1, 2009a.

Wang, H. and Feingold, G.: Modeling Mesoscale Cellular Structures and Drizzle in Marine Stratocumulus. Part II: The Microphysics and Dynamics of the Boundary Region between Open and Closed Cells, J. Atmos. Sci., 66, 3257-3275, doi:10.1175/2009jas3120.1, 2009b.

Wang, H. and McFarquhar, G. M.: Modeling aerosol effects on shallow cumulus convection under various meteorological conditions observed over the Indian Ocean and implications for development of mass-flux parameterizations for climate models, J. Geophys. Res.-Atmos., 113, D20201, doi:10.1029/2008jd009914, 2008a.

Wang, H. and McFarquhar, G. M.: Large-eddy simulations of the diurnal cycle of shallow convection and cloudiness over the tropical Indian Ocean, Q. J. Roy. Meteor. Soc., 134, 643-661, doi:10.1002/Qj.238, 2008b.

Wang, M., Ghan, S., Ovchinnikov, M., Liu, X., Easter, R., Kassianov, E., Qian, Y., and Morrison, H.: Aerosol indirect effects in a multi-scale aerosol-climate model PNNL-MMF, Atmos. Chem. Phys., 11, 5431-5455, doi:10.5194/acp-11-5431-2011, 2011.

Wang, M., Ghan, S., Liu, X., L'Ecuyer T., Zhang, K., Morrison, H., Ovchinnikov, M., Easter, R., Marchand, R., Chand, D., Qian, Y., and Penner, J.: Constraining cloud lifetime effects of aerosols using A-Train Satellite observations, Geophys. Res. Lett., 39, L15709, doi:10.1029/2012GL052204, 2012.

Wood, R.: Cancellation of aerosol indirect effects in marine stratocumulus through cloud thinning, J. Atmos. Sci., 64, 26572669, doi:10.1175/Jas3942.1, 2007.

Wood, R., Bretherton, C. S., Leon, D., Clarke, A. D., Zuidema, P., Allen, G., and Coe, H.: An aircraft case study of the spatial transition from closed to open mesoscale cellular convection over the Southeast Pacific, Atmos. Chem. Phys., 11, 2341-2370, doi:10.5194/acp-11-2341-2011, 2011a. 
Wood, R., Mechoso, C. R., Bretherton, C. S., Weller, R. A., Huebert, B., Straneo, F., Albrecht, B. A., Coe, H., Allen, G., Vaughan, G., Daum, P., Fairall, C., Chand, D., Gallardo Klenner, L., Garreaud, R., Grados, C., Covert, D. S., Bates, T. S., Krejci, R., Russell, L. M., de Szoeke, S., Brewer, A., Yuter, S. E., Springston, S. R., Chaigneau, A., Toniazzo, T., Minnis, P., Palikonda, R., Abel, S. J., Brown, W. O. J., Williams, S., Fochesatto, J., Brioude, J., and Bower, K. N.: The VAMOS Ocean-Cloud-AtmosphereLand Study Regional Experiment (VOCALS-REx): goals, platforms, and field operations, Atmos. Chem. Phys., 11, 627-654, doi:10.5194/acp-11-627-2011, 2011b.

Woodhouse, M. T., Carslaw, K. S., Mann, G. W., Vallina, S. M., Vogt, M., Halloran, P. R., and Boucher, O.: Low sensitivity of cloud condensation nuclei to changes in the sea-air flux of dimethyl-sulphide, Atmos. Chem. Phys., 10, 7545-7559, doi:10.5194/acp-10-7545-2010, 2010.

Yang, M., Blomquist, B. W., and Huebert, B. J.: Constraining the concentration of the hydroxyl radical in a stratocumulus-topped marine boundary layer from sea-to-air eddy covariance flux measurements of dimethylsulfide, Atmos. Chem. Phys., 9, 92259236, doi:10.5194/acp-9-9225-2009, 2009.

Yang, M., Huebert, B. J., Blomquist, B. W., Howell, S. G., Shank, L. M., McNaughton, C. S., Clarke, A. D., Hawkins, L. N., Russell, L. M., Covert, D. S., Coffman, D. J., Bates, T. S., Quinn, P. K., Zagorac, N., Bandy, A. R., de Szoeke, S. P., Zuidema, P. D., Tucker, S. C., Brewer, W. A., Benedict, K. B., and Collett, J. L.: Atmospheric sulfur cycling in the southeastern Pacific longitudinal distribution, vertical profile, and diel variability observed during VOCALS-REx, Atmos. Chem. Phys., 11, 50795097, doi:10.5194/acp-11-5079-2011, 2011.
Yang, Q., Gustafson Jr., W. I., Fast, J. D., Wang, H., Easter, R. C., Morrison, H., Lee, Y.-N., Chapman, E. G., Spak, S. N., and Mena-Carrasco, M. A.: Assessing regional scale predictions of aerosols, marine stratocumulus, and their interactions during VOCALS-REx using WRF-Chem, Atmos. Chem. Phys., 11, 11951-11975, doi:10.5194/acp-11-11951-2011, 2011.

Zaveri, R. A., Easter, R. C., Fast, J. D., and Peters, L. K.: Model for Simulating Aerosol Interactions and Chemistry (MOSAIC), J. Geophys. Res.-Atmos., 113, D13204, doi:10.1029/2007jd008782, 2008.

Zaveri, R. and Peters, L. K.: A new lumped structure photochemical mechanism for large-scale applications, J. Geophys. Res., 104, 30387-30415, 1999.

Zhang, Y., Wen, X. Y., and Jang, C. J.: Simulating chemistryaerosol-cloud-radiation-climate feedbacks over the continental US using the online-coupled Weather Research Forecasting Model with chemistry (WRF/Chem), Atmos. Environ., 44, 3568-3582, doi:10.1016/J.Atmosenv.2010.05.056, 2010.

Zheng, X., Albrecht, B., Jonsson, H. H., Khelif, D., Feingold, G., Minnis, P., Ayers, K., Chuang, P., Donaher, S., Rossiter, D., Ghate, V., Ruiz-Plancarte, J., and Sun-Mack, S.: Observations of the boundary layer, cloud, and aerosol variability in the southeast Pacific near-coastal marine stratocumulus during VOCALSREx, Atmos. Chem. Phys., 11, 9943-9959, doi:10.5194/acp-119943-2011, 2011.

Zuidema, P., Leon, D., Pazmany, A., and Cadeddu, M.: Aircraft millimeter-wave passive sensing of cloud liquid water and water vapor during VOCALS-REx, Atmos. Chem. Phys., 12, 355-369, doi:10.5194/acp-12-355-2012, 2012. 